University of Louisville

ThinkIR: The University of Louisville's Institutional Repository

\title{
A study of the success of the graduates of ten classes of the Louisville Male High School in the first two years in the College of Liberal Arts of the University of Louisville.
}

James E. Green

University of Louisville

Follow this and additional works at: https://ir.library.louisville.edu/etd

Part of the Educational Assessment, Evaluation, and Research Commons

\section{Recommended Citation}

Green, James E., "A study of the success of the graduates of ten classes of the Louisville Male High School in the first two years in the College of Liberal Arts of the University of Louisville." (1938). Electronic Theses and Dissertations. Paper 1802.

https://doi.org/10.18297/etd/1802

This Master's Thesis is brought to you for free and open access by ThinkIR: The University of Louisville's Institutional Repository. It has been accepted for inclusion in Electronic Theses and Dissertations by an authorized administrator of ThinkIR: The University of Louisville's Institutional Repository. This title appears here courtesy of the author, who has retained all other copyrights. For more information, please contact thinkir@louisville.edu. 


\title{
UNIVERSITY OF LOUISVILLE
}

A STUDY OF THE SUCCESS OF THE GRADUATES OF TEN CLASSES OF THE LOUISVIIIE MAIE HIGH SCHOOI IN THI EIRS TWO YELRS IN THE COLLEGE OF IIBARAI ARTS OF THE UNIVERSITY OF LOUISVIIIE

\author{
A Dissertation \\ Submitted to the Fraculty \\ of the Graduate School of the University of Louisville \\ In partial sulfillment of the \\ Requirements for the Degree \\ of Master of Arts
}

Department of Education

by

James̀ E. Green

1938 
Name of student:

Title of Thesis: A STUDY OF THE SUCCESS OF THE GR DUATES OH TEN CIASSES OF THE LOUISVILIE MAIE HIGH SCHOOL IN THE FIRST WWO YQURS IN THE COLIEGT OF IIBERLI ARMS OF THE UNIVERSITY OF LOUISVIILE

Name of Director:

Approved by a readin lcommittee composed of the following members:

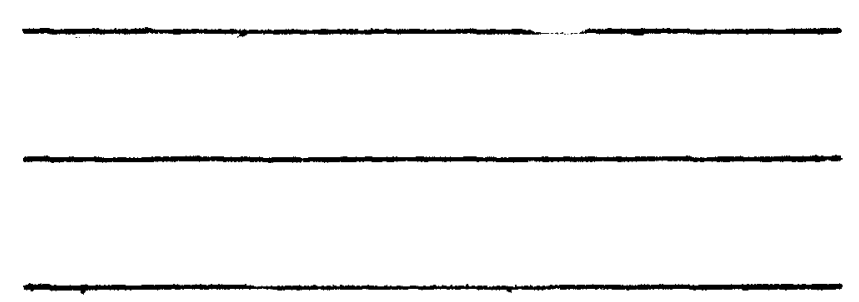

Representetive of the Nnglish Department:

Dato: Sophember 13,938 
A STUDY OF MHE SUCCESS OF THO GRADUATES OF TEN CIASSES OF THE IOUISVIIIE MALE HIGH SCHOOI IN IHE FIRST TWO YEARS IN THE COLIEGE OF IIBERAI ARTS OF THE UNIVEISIIY OF LOUISVIIIE 
TEBIE OF CONTENSS 


\section{TABLE OE CONIENTS}

CHAPTER

NITIE

PAGE

I

Introduction

1

II

Survey of Iitereture Pertaining to the study

6

III

The High School Beckground of

421 College students

18

IV

The College Background of 421

High school Greduatea

32

V

Distribution of Grades and

Comparison of Quartiles

61

VI

Comparisons of Items from I.M.H.S. Records with Criterie from the

U. of I. Records

75

VII

Summary and conclusion

103

Bibliography

112 


\section{IIST OF MABIES}

1 Percentages by Classes of I.M.H.S. Groductes Who Entered the $J$. of I., Who Attended other colleges, and Who Did lot ittend College

2 Averages of Junior-senior Scholastic Grades At I.M.H.S.

3 LVerages of I.2. Scores for I.M.H.s. Gradurtes Who Entered the U. OI I., Who Attended other Colleges, and who Did Not Attend College

4 Average Renk in Graduating Cless of I.M.H.S. Gradiates Who Entered the U. of I.

5 Averages of the figes of I.M.H.S. Graduates Who Entered the U. of I., at the Date of Their Graduction from I.M.H.S.

6 Average Number of credits keceived in I.M.H.S. by Gradurtes Bntering the U. of $I$.

7 herages of scores hade by I.M.H.S. Gracuates on U. of I. Placement Tests, Given by Percentiles

8 Averages of the Tumber of Hours Darned the First Year in the U. of I. by I.M.H.S. Gradustes

9 Avergges of the Number of Hours Earned the Fourth sernester in the L. of L. by I.I. I. S. Graduetes and Avereges of the Fotel Number of Hours Earned in Four semesters

10 Avereges of the Number of curlity Points jarned the First and second semesters by I.M.H.S. Graduates at the U. of I.

11 HVerages of the rumber of gulity points gerned the Eourth semester by I.M.H.S. Greduates at the $\mathrm{U}$. of $\mathrm{I}$. and iverages of the Total Number of Quglity Points Rerned during Four Semesters 
12 qualty joint stending of I.M.H.S. Graduates at the U. of I. the First, Necond, Fourth, and rotel of Four semesters

13 Guartile Distribution of I.M.H.S. Gracuates According to wality Point standing the

Nirst wemester at the U. of $I$.

14 Number of Chences in 100, of I.M.H.S. Gracuetes stteining certain Gulity point Standings the irst semester at U. of $L$.

15 uartile Distribution of I.I.H.S. Graduates According to number of Semesters Enrolled at the U. of I.

16 Number of Chances in 100, of I. H. H. S. Gracuetes Remaining One to Eight Semesters at the U. of

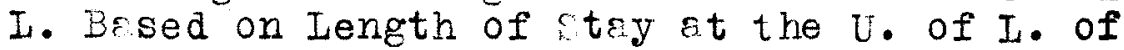
285 students in seven I.M.H.S. Graduating Classes from 1930 through 1933

17 Number of chances in 100, of I.J.H.S. Graauates Cemaining one to Four semesters ot the $\mathrm{V}$. of I. Besed on length of Stry at the U. of I. of 258 students in men I.M.H. s. Gradurting Classes from 1930 through $1934 \frac{1}{2}$

18 Averages of the Percentiles Achieved by I.M.H.S. Grejuates on the Sophomore Comprehensive rests at the U. of I.

19 Percentages of L.M.H.S. Graduates lecording to the Grades received the pirst Yerr at the U. of $I$. and the same percenteges for the Entire College

20 Percentages of I.M.H.S. Graduates ficcording to the Grades Keceived the second Yerr at the $U$. of $L$. and the same percenteges for the Entire College 
21 uartile Distribution of quality points Received by L.M.H.S. Greduetes the First Semester at the U. of $I$.

22 uartile Distribution of Guelity Points Received by I.in.H.S. Greductes the First Four semesters at the U. of $I$.

23 Correlation between Grades Received in I.M.H.S. ond Gredes Received the First Semester at the U. of I.

24 Correlation between Grades Received in I.M.H.S. and Grades Keceived for Four Semesters at the U. of I.

25 Percentages and Numbers of I.M.H.S. Greduates Separated According to Ages at Date of Graduation and classified by the Number of Quality points Keceived the First semester at the U. of I.

26 Percentages and Numbers of I.M.H.S. Graduates Separated According to cuertiles and Classified by the Number of quality Doints Received the First Semester at the U. of $I$.

27 Percentages and livmbers of L.ir.H.S. Greduates Separated According to Number of I.M.H.S. Credits in themetics and classified by the Number of cuelity points Received the First Semester at the U. of I.

28 Averages of Numbers of semesters in sttendance at the $U$. of $I$. of the Iowest one-Third of Each of Ten Classes Gradueting from I.H.H.S.

29 Numbers of parents and percentages of the occupetions of Ferents of I.H.H.S. Greduetes fittending the $U$. of $I .$, and the Verious classificetions of Each

30 Percentages ena Numbers of I.in.t.S. Greduetes Separeted Accoraing to occupetions of perents and classified by the Number of cuelity pointa Derned the First semester at the $\mathrm{t}$. of $I$. 
31 Correlation of scores on the Psychological

Plscement lest at the U. of I. with tho

Averages of L.I.H.S. Scholastic Gredes

32 Correlation of Grades in English in I.M.H.S. for Four Years with Gredes in English at

the U. of I. for the First Year

33 uertile Distribution in L.M.H.S. and in the U. of I.

34 Number of Chances in 100, of quartile Distribution in I.M.H. B. Being Retrined in the $U$. of $I$. 
Chapter I

INIRODUCIION 


\section{INSRODUCTION}

What becomes of the high school boy after graduation? How successful is he in college? Teachers may wonder what becomes of their students, for beyond a few accidental contacts or cursory information, they do not know. This study is not an attempt to follow up all the students, or to discover the interests of a few, or to examine the occupations of any; it is to find out what success the graduates of ten consecutive classes have had during their first two years at the college of Iiberal Arts of the University of Louisville. We want to indicate whether it would be reasonable to establish a basis of prognosis. We want to know if we can set up an advisory procedure. The present investigetion may be interpreted as an attempt to find out (I) whether there is a sufficient degree of correlation between high school and college records to warrant definite attempts to counsel graduates and (2) whether the records of graduates in the high school are sufficient to predict success in college.

In the Louisville Male High School, scholastic gredes are given numerical values, and success may very from seventy per cent to one hundred per cent. More students attoin an average between seventy ond eighty per cent than attain an average between eighty-five and one hundred per cent. An average of eighty-five per cent cualifies student to become 
a member of the Cum Iauãe society, which is a national honor society of which the Iouisville Male Hi sh school is a member. We may point out thet while success is intangible, boundaries may be fixed or goals set or aims for achievement established. In this study, the word success is used to indicete whether the student has conformed to two sets of standerds, one established by the Louisville Male High School and the other by the College of Iiberal Arts of the University of Iouisville. Whether or not these standards ere so fixed as to be true messures is not the purpose of this inquiry. The existing standerds have been accepted and used in determining the facts of this study.

The ten gredusting classes of the Louisville lale High School from June, 1930, to Eebruary, 1935, inclusive, totaled 1511 graduates. Four hundred and thirty-six of this number have enrolled in the college of Iiberal Arts of the University of Louisville. This number is sufficient to present indicetions of the trenda in the verious phases of high school and collegiate records studied.

One of the purposes of this study is to interest the faculty of the Louisville Mele High School and particularly the members of the nethenetics Depertment, of which the writer is a member, in the progress of pupils whose foundetions of success should have been laid in high school. Too often the ultimate goal of the teacher is the graduation of the pupils, 
and there is a noticeable leck of interest in the later progress of the graduates. Whether it is possible to measure the success of greduates and translate the findings into terms that are meaningful to the instructors remains to be studied. Since only the first two years of college work are to be studied, the success of the graduate during that period only will be considered. No attempt has been made to enumerate reasons for abandoning the college course, or to follow up subsequent educetion of graduetes in institutions other than the College of Iiberal Arts of the University of Louisville, or in other colleges of the University of Iouisville than that of Iiberal Arts. If a student completes two years of his college course with satisfactory scores on the placement Nests and Sophomore Nests, and with isfactory gredes in various subject fields, then he is deemed to have succeeded.

The words Louisville Male High School and College of Liberal Arts of the University of Louisville will bo used often enough to take up apace unduly, so that from now on the abbreviations I.M.H.S. and U. of I. will be employed.

Since each entrant in the $U$. of $I$. is given at least one placement test in some fiela, the correlation between such a test and the I.a. score or the correlation between such a test and the average grade received from L.M.H.S. is of value. The sophomore Mests may be used as measures of ettainment in the first two years of college. 
The accumulation of data in the U. of I. for placement Tests and Sophomore Mests shows thet different methods have been used in different years in recording test scores with the resulting deta not complete for all students. One plecement Test and one Sophomore lest, at least, were raministered to each student who completed two years of college work.

The data used in the present study were taken from the permanent record files of the I.M.H.S. and from the office of the Registrar st the U. of L. For some graduating classes the I. a. score records are so incomplete that no correlations can be obtained. When the I.Q. scores are compared with scores on Placement Tests, little significance can be attached to the correlation since few L.M.H.S. graduates had both scores.

A further purpose of this study is the establishment of significant criteria to eliminate students whose chances for success in college are at a minimum, and to eneble the high school counselor to advise graduates wisely. If it is possible to set up such criteria thet a student who has a certein rank and a certain I.Q. score, whose average for his junior and senior years is so much, and whose perents are engaged in a given occupation, may know what his chances of success are at the U. of I., we shall have substituted deta for opinion. 
Questions to be answered in this study:

1. Do I.M.H.S. graduates whose grades ere highest enter the U. of I., go to other colleges, or not enter college?

2. Do L.M.H.S. graduates whose I.G. scores are highest enter the U. of I., go to other colleges, or not enter college?

3. Is the first year of college more difficult than the second?

4. Has the age of the I.M.H.S. graducte any significance in his success in the U. of I.?

5. When do the lowest one-third of the graduetes drop out?

6. Does the rank in the graduating class indicote the number of cuality points earned the first semester?

7. Is there any relationship between the occupation of the parent and the success of the I.M.H.S. graducte at the U. of I.?

8. Does the study of mathematics in I.M.H.S. Increase a student's chance for success in the U. OI I.?

9. Is there any correlation between the L.M.H.S. scholastic averages and scores on the psycholugical rest?

10. Is there any correlation between grades for Engiish in I.M.H.S. and in the U. of I.?

11. Which group succeeds in the U. of I.? 


\section{Chapter II}

A SURVEY OF PHI IIMWRANURE

PERTLINING TO TIE SIUDY 


\section{II}

\section{A SURVEY OF IHE IITERANURE \\ PERMAINING TO THE STUDY}

When the literature on the subject of success in $\operatorname{colleg} \theta$ is survejed, two pheses ere seen to be recurrent throughout the meteriel. One of them is articuletion, which implies guidance, and the other is prediction, which infers statistical measurement. Whe has been written upon both aspects of the student's progress, on the one hand whether it is best for the high school graduate to attend college and on the other hand, what his chances of success are if he does attend college. The two questions are mutually dependent; so it does not matter which one is considered first. Iet us take up articulation, for it perhaps hes a broader range.

As an introduction to the problem and to the literature on the subject, we can do no better then to quote from the Foreword of the Reserrch Bulletin ${ }^{l}$ of the Netionel Eductional Association, which was written by Givens. "Nowhere is the problem of articulation more troublesome than for high schools and colleges, where the problem is complicated by traditional differences in purpose and procedure, by tremendous growth of both institutions during the past fifty years, and by the rapid chenges in policy and prectice now taking plece thruout

1. Givens, Willerd E., "Foreword." Research Bulletin of the National Bducational Association, Merch, 1938. p. 64 
the field of educetion. Neither the high school nor the college has been unmindful of, or indifferent toward, the imperfect articulation existing between them; but recent trends are forcing them to reeviluate their efforts to bring about grester unity. Frequently and earnestly inquiries such as the following are voiced: Is it possible so to coordinate the work of high school and college that the latter will receive from the high school those best fitted for college education? can the dificulties of student adjustment be lessened so that more of those who enter college will remain and make the most of their opportunities?" A negetive reply to Givens' question is voiced by Eells, ${ }^{1}$ who says, "Some schools are not doing a satisfactory piece of guidence but in many cases are encouraging their graduates to enter higher educational institutions in which their probability of failure is relatively high." Perhaps not so strongly stated but equally decisively is Brommel's ${ }^{2}$ observation that, "The National Survey of Secondery Education revealed that the grectest hindrance to improved articulation between the secondary school and the college is the lack of effective guidance programs in both secondary and higher education."

1. Eells, Walter E., "The Collegiate success of Secondary School Graduates," Journel of the Americen Association of Collegiate Registrare, April, $1938 . \bar{p} \cdot 299$

2. Brammel, P. Roy, "Articuletion of High School and College," Nationel Survey of Secondary Eucation, Monogreph No. 10 U.S. Office of Education. 1932. p. 93 
Upon whom does the educational burden of orientation fall? From the Reserrch Bulletin of the N.E.A. ${ }^{1}$ we quote, "Ready adjustment to the new environment of the college on the part of an entering student often hinges on how quickly and how thoroly the proper college authorities become acquainted with him and his needs." To make such a transition Segel2 says, "For effective guidence of students into college work it is necessary to be able to make some articulation between the student's capacities and interests and the program of studies offerea in the college or university."

Why is the necessity to have an extensive guidance program greater now than formerly? Perhaps as the Research Bulletin of the N.E.A. 3 states, "Approximately five times as many students are now in college as there were at the opening of the century. With this rapid growth in enrolment, the disparity hes incressed in the cultural and social beckground of college students, and in their respective abilities and interests." Another reason for the college awakening to the need for thorough guidance, according to Hartmen ${ }^{4}$, is thet, "Institutions of higher education in the united states have been severely criticized beceuse of the seemingly unwarranted

1. Givens, op. eit., p. 102

2. Segel, Devid, "Prediction of Success in College," Bulletin No. 15, U.S.Office of Eucation, U.S.Government Printing Office, Washington, D. C., 1934. p. I

3. Givens, op. cit., p. 65

4. Hertman, Helen J., "Pre-College Guidance in Ohio," The School Review, November, 1937. p.662 
amount of failure and elimination of students which occurs, particularly during the Freshmen yoar." Then the same author places the blame. "A review of the literature reveals a rather general agreement. . . that the secondary school has failed in... (1) helping pupils to decide whether they should go to college, (2) giving guidance to pupils who have declared their intention of going to college." In confirmation of this last utterance, the N.E.A. Research Bulletin ${ }^{l}$ says, "Ono of the important guidance functions generglly conceded to belong to the high school is that of helping students to decide whether or not they shoula go to college." Again from the N.E.A. Bulletin ${ }^{2}$ we read, The obvious need for better guidence procedures for college freshmen is driven home by statistics on first year failures. Bach elimination shows that the gap between high school and college has been too wide, at least for the student involved. Any effective program for bridging the gap between high school and college, moreover, must look to something more than the prevention of failures and a reduction in the number of freshman withdrawals." one method of eliminating particular failures is voiced by Mequitty, 3 ". . . thet sound high school foundation is more essential for success in college Fnglish, mathematics, and langueges then it is for success in college sociel sciences,

1. Givens, op. cit., p. 70

2. Ibid., p. 66

3. McQuitty, John V., "Relative Scholarship of Graduetes According to Accreditation of High Schools," Journal of $\frac{\text { the American }}{\text { April, } 1934 .} \frac{\text { Association }}{\text { p. } 188}$ of Collegiate Registrar8. 
and other academic subjects."

The N.E.A. Bulletin ${ }^{1}$ shows that, "Widespread acceptance on the part of high achools of some measure of respongibility for advising students with respect to college entrance is indicated by the fact that, in giving this type of counsel, two-thirds of the schools included in this study follow some regular procedure." On the college level Johnston ${ }^{2}$ says of guidance, "In connection with the counseling system. . . . continuous efforts have been made to discover valid information to be given entering freshmen regarding their prospects for success in college. . . to save students from fallure." Also on the college level Ficken" mentions the "Efforts to avoid the appalling amount of waste occasioned by the high percentage of fallures in the early semesters of college attendance. . .pre-college testing and guidance. . .with better selection of students. . . and elimination. . . of bad college riskg."

An appreciation of the situation with a general analysis of means of prevention is suggested by wood ${ }^{4}$ wen he states, "Our control of high school-college articulation depends in the last analysis on the extent and quality of the information

I. Givens, op. cit., p.III

2. Jomston, J. B. and Wiliamson, E.G., "A Follow Up stuay of Early scholastic Predictions in the University of ininnesota," School and Society, December 1, 1934. p.730

3. Ficken, C.E., "Predicting Achievement in the Liberal srts College," School and Society, October 12, 1935. p.518

4. Nood, Ben D., "The UItimate Basis for Satisfactory CollegeHigh School Relations," Journal of the American Association of Collegiate Registrars, July, $1934 . ~ p .271$ 
about individuals that is secured and wisely used before admiggion to college, during the admission and placement procedure, and after admission." In affirmation of this view we see from the N.E.A. Research Bulletin that, "A factor cited by college authorities as essential to a satisfactory plan for selecting students was adequate acqualntance with the prospective student and his achievements growing out of close cooperation with the high school which he attended." A more practical suggestion is made by $\mathrm{Crawford}^{2}$ who thinks, "Reliable estimates of individual students' fitness for college work are obviously important in determining whether or not they should be admitted." Then he says, "If an institution finds it unwise to admit more than a certain number of candidates, it must be able first of all to justify its selections upon intellectual standards." A more definite stand is taken by Byrns ${ }^{3}$, who raises another question by asking, "Is it possible for the boy who rates low in a standard psychological or college aptitude test and who gets low grades in high school to succeed in college work? Does the young man of great aptitude always win the best grades in college?" She believes, "Recognition of the relationship that exists between the quality of achievement in high school and in college work is

1. Givens, op. cit., p. 112

2. Crawford, A. B., "Forecasting Freshman Achievement," School and Society, January 15, 1930. pp. 125-132.

3. Byrns, Ruth, "Predicting College Success by High School Grades," The Nation's Schools, July, 1932. p. 30 
one step towerd constructive guidence." The same writer summarizes whet hes been said of the problem of guidance and suggestions for its solution wher she ststes, "Only thet advice and guidrnce which are built on fects cen be of genuine velue to the irdividuel end to the educationel system." The second pert of the litersture in the field urier investigetion degls vith records and their stetisticel treatment. In particulfr as petrengill' states, "mwo factors which are more or less universelly considered in admitting and counseling college Ireshmen ere scores on college eptitude tests and high school records." There Eppeers to be some disagrement as to what pert of the high school and college records is most valusble for guidance. Gowen ${ }^{2}$ seys, ". •. marks in different high school subjects were not very indicative of what subjects the individual would do best in college." This stand is elso teken by perguson who conclvdes that, "Grodes in secondery school are so heterogeneous thet they correlate only .30 with grades in the college. When the difference between \& student's avergge grede axid the pessing grade of the school is teken as the criterion, the result is also precticelly worthless." Mhis stetement is refuted by

1. Peitengill, "rrue E., "gize of figh school End Predictive value of class Renk and fptitude cest kank," Journel of the Amerioen hssocietion of Collegiste Fegistrers, $4 \overline{p r i l, ~} 19 \overline{34} \cdot \bar{p} \cdot \overline{190}$

2. Gowen, J.W. and Gooch, M., "The Hentel Attrinments of college Students in Reletion to previous Praining," Journel of Educationel Psychology, November, 1925. pp. 547-568

3. Ferguson, George 0., "Some Fectors in predicting College Success," School and Society, April 29, 1933. p. 566 
Gladfelter ${ }^{2}$ when he asserts, "There is a correlation of .68 between the numerical high school average, when all major subjects are considered, end the everage grade made at the end of the Freshman year." He further states thet the correlation between high school English and Freshman English is .59, and the correlation between the high school avergge and the Americen Council Psychological Test is .58. Iikewise Edds ${ }^{2}$ finds, "Intelligence correletes .502 with the composite of first semester marks."

The Reserrch Bulletin of the M.E.A. ${ }^{3}$ mentions as frets teken into account in counseling, "(I) scores from tests given in connection with college entrance (2) teachers merks which the student received on related high school subjects (3) scorea on achievement tests given in high school (4) age (5) general intelligence." The sane Bulletin ${ }^{4}$ reports that, "The importance of records and reports is brought out repeatedly in this review of guidance procedures." so far as the predictive value of records as used is concerned, Reitz ${ }^{5}$ says, "...after

1. Gladfelter, lifilard E., "The Volue of Severel Criteria in Predicting College success," Journal of the American Association of Collegiate hegistrars, April, 1936. p.187

2. Edds, J. H. and IcCell, W. M., "Predicting the Scholestic Success of college Freshmen," Journgl of Dacational Research, October, 1933. p. 128

3. Givens, op. cit., p. 90

4. Givens, op. cit., p. 113

5. Reitz, Wilhelm, "Predicting college fchievement with Merks and Renks Adjusted for Inter-High School Variability," Journel of the fmericen Associetion of collegiete Registrars, April, 1934. p. 181 
all some of these treditionel standards for selecting good student material make, in reglity, only a small contribution in the determination of college achievement. While. . this is in part due. . ., the writer is rather inclined to believe that actuel absence of reletionship between these measures and college success is the fundamentel trouble."

Just what records may be used in predicting the success of high school graduetes is a controvereigl point. Gladfelter ${ }^{l}$ says that, "The unit and subject mark heve given way to such factors as renk in cless, ratings on intelligence, psychological and achievernent tests." Thurber ${ }^{2}$ thinks, "Whetever evidence there is seems to indicete g.gain that the ranking based on secondary school maris is of more import than the psychological test rankings." Newsom" states, ". . a good high school recora, regardess of the pattern of subjects teken, when combined with a standara intelligence test score, is the best basis for selecting candidetes for college admission." The same author ${ }^{4}$ says, "The investigation of

1. Gladfelter, Nillerd E., "Status and Frends of College Entrence Requirements," The School Review, Decenber, 1937. p. 747

2. Thurber, C.H., "Is Scholarship Renking Useful for Prediction?" School End Society, nerch II, 1933. p. 328

3. Newsom, 1.W. and Sturm, H.J., "Comparison of the college and High School Wr res for lon-Greduating College students," Journal of the Americen Association of Collegiate Registrars, $\Lambda$ pril, 1937. p. 217

4. Nowsom, op. cit., p. 217 
Garrett concluded from study of 324 records that results during the last two years of high school were superior as a basis for predicting college success, while certain subjects such as English and Mathematics, had greater predictive value." Newsom further deduces that, "The results that Douglass obtained showed that the best single type of predictive data is the average high school marks; the score on an intelligence test is the only other factor which increased the accuracy of the prediction." The seme writer ${ }^{2}$ concludes, "Since the students achieved on an average approximately one grade lower in college then in high school, it is likely that all students who enter college with a high school average of $\mathrm{C}$ or lower will not attain the scholastic standing of $\mathrm{C}$ or better in college, which is generelly recuired for continuance in college. The failure of colleges to require such standards is probably the cause of $\varepsilon$ large percentage of student mortality." on the same topic segel ${ }^{3}$ asserts, "For the school where a grade of $\mathrm{C}$ must be mainteined in order to insure graduation, the $C$ grade is the basis for considering whether the student is a success as to whether he can meintein an average of c." Byrns $^{4}$ says, "Thus a low score in the psychological test

1. Newsom, op. cit., p. 218

2. Nowsom, op. cit., p. 221

3. Segal, op. cit., p. 15

4. Byrns, op. cit., p. 30 
promises poor college work much more certainly then 8 high score promises success." A more optimistic view is taken by Johnston ${ }^{l}$ in speaking of certein deta which, ". . showed that college scholarship could be predicted with a high degree of success from high school percentile rank and the college aptitude test." But Segel ${ }^{2}$ thinks, "However, from the evidence collected to date there seems to be no reason for changing our criterion of college success from scholarship in the college subjects to length of stay in college." The scholarship should be thet of the freshman year, for as zorbaugh 3 states, "A certain grade-getting ability seems to accrue to the student by virtue of his experience or orientation as he progresses in college." In ranking the merits of different items of the recoras pettengill 4 believes, "whe renk in high school gradueting class is statistically a more relieble index than the college aptitude test for the prediction of freshman scholarship. The aptitude test epparently does not add anything to the relibbility of prediction." In referring

1. Johnston, op. cit., p.731

2. Segel, op. cit., p. 7

3. Zorbaugh, Grace S.I. and Kuder, G. F., "College Grades and the Vocetional jotive," School and Society, July 10, 1937. p. 63

4. Pettengill, Prue E., "Comperison of the College Aptitude Test and Rank in High School Gradurting Class as Fectors for Predicting Freshman Scholership," Journal of the American Association of Collegiate Fegistrarg, April. 1936. p. 203 
to the same measure cuttle ${ }^{1}$ says, "As with other predictive measures, doubtless the rank in high school cless loses some of its value in the midale groups." Eells ${ }^{2}$ argues, "fis one of the most significant indices of success of a school's product. - average percentage of hours of work failed during the first year or semester of their attendance." The opinions of other writers seem to be at variance. AII of the idess suggested by the writers quoted cannot be used in measuring the success of I.M.H.S. graduetes at the U. of I.; therefore, we shall choose the items best suited to the data.

1. Muttle, C.P., "The Predictive Value of Renk in High school Graduating Ciass," Journel of the Americen Associetion of Collegiate Registrars, Janue. 2. $\overline{\text { Eel Is, op. cit., p. } 295}$ 


\section{Chapter III}

TIE I.M.H.S. BACKGROUND OF $421 \mathrm{U}$. OF I. STUDENTS 


\section{III}

MHE I.M.H.S. BACKGROUHD OF

421 U. OF I. STUDENMS

Historical Foreword. I "Although based on a former academic institution, the Louisville Male High School, as such, was first opened in 1856, at finth and Chestnut. After about forty years of honorable achievement it was moved in 1894 to the site now occupied by the Theodore Ahrens Mrade School, on First Street near Chestnut.

"In $1915 \mathrm{I} \cdot \mathrm{I} \cdot \mathrm{H} \cdot \mathrm{S}$. was consolidated with the duPont Manual Training High School. The present building at Brook and Breckenridge, erected at a cost of over a guarter of a million dollars, was occupied in the fall of that year.

"For four years it was known as the Louisville Boys' High School. At the end of that time the two schools were again separated and shortly after that the old name was restored.

"The entire history of the school from its beginning is the story of a continuous effort to adjust itself to the needs of the comunity. Founded at a time when the idesl of education was an essentiglly aristocratic ideal of bookish culture to prepare its students for the leerned professions,

1. Fifteenth Edition of the Iouisville MEle High School ' $\mathrm{H}$ ' Book. p. 9 
it began early to modify this ideal as the situation demanded. Beginning with the old classical curriculum, it gradually added the scientific branches, physical training, athletica, modern languages, business courses, music, art, and military training. The school was not to be considered a repository of arbitrary standards by which the pupil was to be measured, and then discerded as unfit, or told there was nothing for him. On the contrary, it was to be a place where he would be taken as he wes, given anything he could absorb, trained to perfect whatever abilities he hed, and sent forth as a useful nember of society, prepered to moke his individual contribution to the social projects of the commity.

"The scientific subjects were introduced in 1869, physical training (in 8. mild form) in 1872, end freehand drawing in 1881, later becoming ravuel treining and causing the founding of a separete school - dupont ifnuel mrining High school. In 1896 there was military drill.

"In 1898 a Commercial High School was organized, whose boys were transferred to Male High sbout ten years later. All these subjects heve stecaly developed, elong with clubs and other extra-curricula activities in order to give ever increasing opportunities to all types of students." At the present time the personnel of the Jouisville Male High school includes a principal, a student counselor, 
forty-nine teachers, three instructors in the R.0.R.C., and a student body of about fifteen hundred boys.

From 1919 to 1932 the course of studies was divided into a clessical course, a Scientific Course, a comercial Course, and $a$ General Course. In 1932 a course of majors and minors wes instituted, which course is in effect at the present time.

Chapter 3 presents the high school background of I.H.H.S. graduates entering the U. of $I$. from the fall of 1930, to February, 1934, inclusive, a total of ten graduating classes. Of the 1511 boys graauating in the ten classes 436 , or $29 \%$, have matriculated in the college of Iiberal Arts of the University of Louisville; 405 , or $27 \%$, have attended other colleges and universities; and 670 , or $44 \%$, have not attended any institution of higher learning. There has been a representative group at the U. of I., the study of whose success by classes should yield worthwhile deta. We shell consider in this chapter the high school records of these graduates. This will serve as the high school background of the student. We shall first consider by classes the percentages of the graduates who entered the U. of I., who entered other colleges, and who did not attend any college after graduation from high school. The percentages are given only to the nearest unit since no perticuler end would be served by greater 
accuracy. The three categories used were determined by records of the L.M.H.S., eccording to the transcripts asked for by various institutions. Since the great mojority of colleges require such transcripts, we feel that this is a sound assumption for so grouping the gradustes. A check of the records st the U. of $I$. refined this classificetion to such a degree that eny error would be slight. This system of compiling the actusl number of ceses for whom records are available at both institutions reduced the total number from 436 to 421 . The reasons for the variations in size of the three categories used during particular jears are beyond the scope of this study.

\section{PABIE 1}

PERCENI GWS BY CLLSSES OF GRADU AES HO FNMYRED MHE U. OE I., WHO ATITIDED ONHPR COLLEGFS, AND WHO DID NOT $/$ IPEND COIIEGE

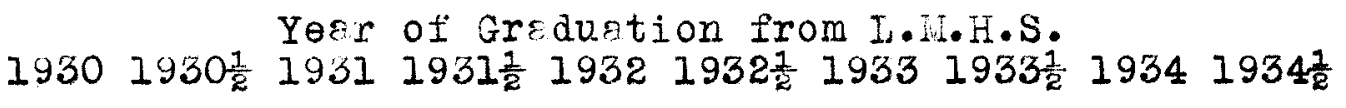

Number in

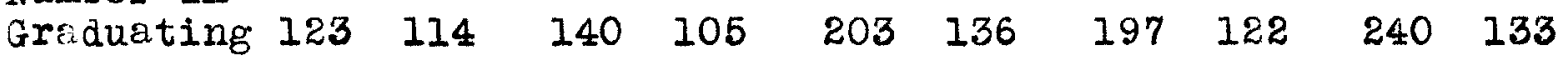
class

Percentege of Grad. $\begin{array}{llllllllll}27 & 37 . & 24 & 33 & 34 & 28 & 23 & 25 & 30 & 35\end{array}$ Entering U. of I.

Percentage of Grad. Entering

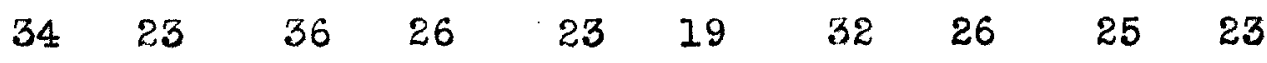
other coll.

Percentage of Grad. Not Entering $39 \quad 40 \quad 40$ 41 $43 \quad 53$ $45 \quad 49$ 
The percentages of I.M.H.S. students attending the U. of I. varied from 23\% in 1933 to $37 \%$ in 1930 $\frac{1}{2}$; the percentages attending other colleges vrried from $19 \%$ in $1932 \frac{1}{2}$ to $36 \%$ in 1931; and the percentages who did not attend college varied from $39 \%$ in 1930 to $53 \%$ in $1932 \frac{1}{2}$. We see that the spread in percentage for the U. of $I$. was 14 , the spread for those attending other colleges was 17 , and for those who did not enter college, 14. The highest percentage of those attending other colleges was at time when the second smallest percentage entered the U. of I. Attendance of I.M.H.S. students was average \&t the $U$. of $I$. when the lowest per cent attended other colleges and when the greatest per cent did not enter college. On the other hand the lowest per cent attended the $U$. of $I$. when the third highest per cent attended other colleges and an overage per cent did rot enter college.

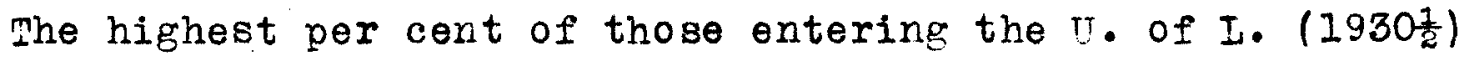
came when the second lowest per cent went to other colleges and the second lowest per cent did not enter college. The fourth smallest class (1930) contained the lowest per cent of those who did not enter college, the highest per cent going to other colleges, and the fourth lowest per cent entering the $U$. of $I$. The largest class (1934) had the highest per cent of eny class not entering college, en avergge per 
cent entering the U. of I., and an avergge per cent going to other colleges.

We see that when a greater percentage went owey to school, a smaller percentege did not enter college, but the percentage attending the $U$. of $I$. was feirly constant. When the trend was not to attend college, the number attending other schools wes always belov: their average percentage, but the percentage attending the U. of $I$. did not vary as much as that of the other college group or the non-college group.

We now compare the sane categories as to the high school average. The grode for graduation at I.M.H.S. is between 70\% and 100\%. The principel recommends for admission to college those gradugtes who attein an average of $85 \%$ and who desire to enter college. The majority of students have an everage between $70 \%$ and $83 \%$. In the present study the junior and senior grades only are considered in averaging, as this average satisfies the entrance requirements of mary colleges.

\section{TABLE 2}

AVERAGRS OT THE JUNIOR-ERITIOR SCHOLASTIC GRADES AT I.IT.H.S.

Groups Year of Graduation from I. H.H. S. $19301930 \frac{1}{2} 1931 \quad 1931 \frac{1}{2} 1932$ No.AV. NO. Av. No. Av. NO. Av. No. Av. U. of I. $\quad 2379.1 \quad 4179.13379 .1 \quad 3482.3 \quad 7081.5$

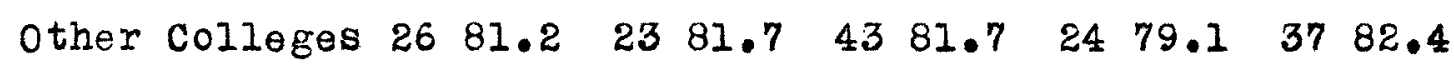
$\begin{array}{lllllllllll}\text { Non-College } & 29 & 79.0 & 41 & 77.1 & 41 & 77.1 & 40 & 78.6 & 73 & 78.9\end{array}$ 


\section{TABIE 2 (continued)}

Groups Year of Gredustion from L.H.H.S. 1932 No. $\mathrm{AV}$. NO. $\mathrm{KV}$. $1933 \frac{1}{2}$ 1934 $1934 \frac{1}{2}$

U. OI I. $\begin{array}{llll}38 & 80.5 & 46 & 80.2\end{array}$

INO. $\mathrm{Av}$. No. Av. No. Av.

other Colleges 1983. $3184.1 \quad 7182.8$

3485.8 Non-College $6479.9 \quad 74 \quad 79.6$ $\begin{array}{llllllll}51 & 84.2 & 25 & 84.5 & 38 & 84.4 & 26 & 84.2\end{array}$

The range tor $U$. of $I_{1}$. Was from 79.1 in 1930 and $1930 \frac{1}{2}$ to 85.8 in $1934 \frac{1}{2}$, a sprecid of 6.7 ; for other colleges, from 79.1 in $1931 \frac{1}{2}$ to 84.5 in $1953 \frac{1}{2}$, 8. spread of 5.4 ; and for those who did not attend college, from 77.1 in $1930 \frac{1}{2}$ to 80.6 in 1934, a spread of 3.5. Helthough the students entering the U. of I. had no high school sverage lower than thet of those at other colleges, and the highest cverage wes greeter, the average was generally greeter for other colleges. Those who did not attend college vere consistently lower in their evercges then either of the other groups, for in no class did their highest sverage resch the lowest verage of the other tro groups. Only in 1931 and 1934 did the average of U. of I. metriculstes exceed thet for other colleges,

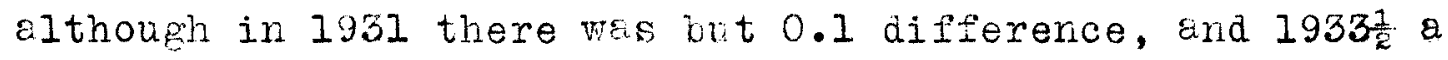
difference of 0.4 .

It would seem thet those greduates of L.H.H.S. who receive the highest avergges in their junior snd senior yeers yo to colleges other then the $U$. of $L$. The difference 
even if it is positive, is not greet erough for the formulation of ny principle. The gredurtes who heve the lowest evereges do not attend college ss a rule.

I. a. scores sre third basis for comparison in the matter of high school records. vite a number of I. C. scores, hovever, were missing. This fact is sufficient to invalidate comperisons for the gredueting clesses of 1930 and $1930 \frac{1}{2}$. The majority of the I.Q. scores were recorded from tests administered in the junior high school. The tests in I.H.H.S. were given only in special cases in which the gredes received were obviously out of line with the I. s. scores.

\section{TIBLI 3}

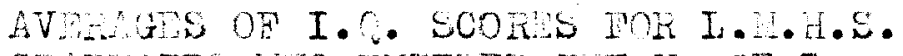

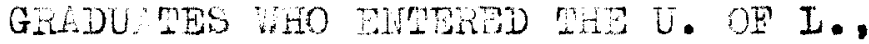
WHO ATMENDED ONH R COLIVGSS, AITD WHO DID NO' AITEND COII EGE

Groups

$$
1930
$$$$
\text { Yegr of Graduetion }
$$

from I.M.H.S. No. Av. MO. Av. NO. Av. Ho. Av. No. Av.

U. of I. $4109.3 \quad 10122.721117 .421 \quad 110.4 \quad 58111.2$ $\begin{array}{lllllllllll}\text { other } & 10 & 114.1 & 10 & 112.1 & 27 & 113.2 & 13 & 108.1 & 29 & 114.7\end{array}$ Colleges

NonCollege

8117.4

9113.6

22108.5

24102.353107 .2 
LAbLE 3 (continued)

Groups

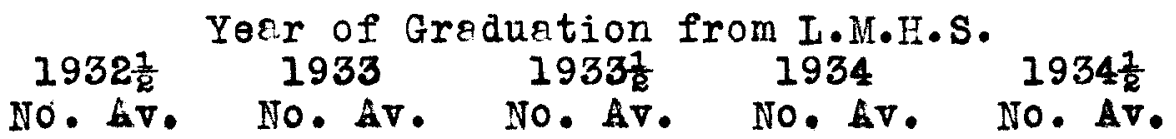

U. of I.

29111.2

34104.6

20114.0

$\begin{array}{llll}57 \quad 110.6 & 26 & 109.0\end{array}$

other

13115.8

$41 \quad 110.5 \quad 16 \quad 115.6$

31114.8

23114.7

Colleges

$\begin{array}{lllllllllll}\text { Non-College } & 40 & 106.7 & 55 & 101.8 & 21 & 103.7 & 67 & 105.7 & 49 & 105.3\end{array}$

The results of the avereges obtained from Table 2 are corroborated by Table 3, namely, that for a comparable number of casea, the graduates of L.H.H.S. Whose I.Q. scores are highest go to colleges other than the U. of I. and those with the lowest I.Q. scores do not enter college. In each case those attending the U. of $I$. have averages slightly lower than those attending other colleges and distinctly higher than those of graduates who do not enter college. The U. of I. attracts greduates of good scholastic standing, but not those of the highest standing. Those pupils who do not enter college are not of $8 \mathrm{~s}$ high standing as those who go to college.

Rank in class also indicates the standing of the I.M.H.S. graduate. Rank in I.M.I.S. is from one, which is high, to the last number in the class. Deciles are from ten, which is high, to one which is the lowest decile. The table of ranks is given in order that a clearer idea may be obtained of the type of student who enters the U. of $I$. 
TABIE 4

AVERAGE RANK IN GREDUATING CIASS OP

I.M.H.S. GRADUATES WHO ENTERED THE

$\mathrm{U}$. of I.

Year of Graduation from I.M.H.S.

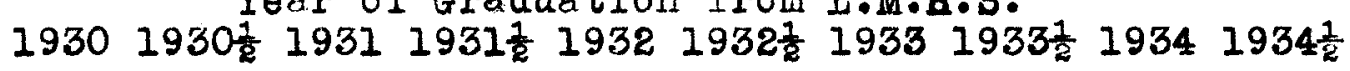

Average

Rank of $66.2 \quad 55.6 \quad 69.6 \quad 39.9 \quad 92.1 \quad 69.9 \quad 110.7 \quad 47.0 \quad 112.244 .7$ Graduate

Number

$\begin{array}{llllllllll}\text { in Grad- } 123 & 114 & 140 & 105 & 203 & 136 & 197 & 122 & 240 & 133\end{array}$ uating

Class

Decilo

into

566

76

$5 \quad 5$

76

7

which

the ave-

rage fells

The average rank of the graduate was never below the fifth decile. Three classes had their avergge in the fifth decile, four in the sixth, and three in the seventh. The figures are not unusually high, neither are the particularly low. Seven of the ten classes rani in deciles above the lower five deciles, the other three in the fifth decile. We can see from this that the average is in the upper five deciles.

one of the usual questions asked by instructors and administrotors is whether students are entering college at a younger age than they did formerly. The results from five years do not answer this cuestion conclusively, but the data 
give an indication of the trend. Several graduetes in each class were above the normal sge because they had been compelled to suspend their educetion for several yeers. These cases, however, were so rare that their influence has but little effect upon the general averge.

\section{MABIE 5}

AVERAGTS OP WHE AGES OP I.M.H.S. GHADUNES WHO ENTDPDD THE U. OT L., AT MHT DARE OR WESIK GRDUAMION FROM I.M.H.S.

Year of Graduction from I. H.H.S. $19301930 \frac{1}{2} \quad 1931 \quad 1931 \frac{1}{2} 1932$ Yr.110.Da. Yr.HO.Da, Yr.HO.Da. Yr.MO.Da. Yr.MO.Da.

Average

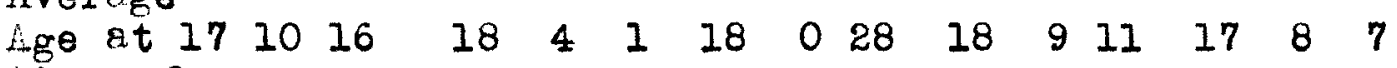
time of Gredurition

$$
\begin{aligned}
& \begin{array}{ccccc}
1932 \frac{1}{2} & 1933 & 1933 \frac{1}{2} & 1934 & 1934 \frac{1}{2} \\
\text { Yr.MO.Da. } & \text { Yr.1Ho.DE. Yr.MO.Dr. Yr.Mo.De. Yr.Mo.Da }
\end{array} \\
& \begin{array}{lllllllllllllll}
18 & 2 & 13 & 18 & 0 & 12 & 18 & 3 & 13 & 18 & 0 & 4 & 18 & 1 & 26
\end{array}
\end{aligned}
$$

From the dete in rable 5 it appers thet there is no especial chenge in sige in reletion to the yeer. The difference between the youngest and the oldest average is one year, one month, and four days, and oddly enough this difference is between successive gradueting clesses, those of $1931 \frac{1}{2}$ and 1932. Another peculierity which may be coincidentel is that 
the average ages are alternately younger and older, beginning with the class of 1930. This fact verified by a check of other classes, would certainly answer negatively the question 8.s to whether boys are entering the U. of I. at a less mature age than was formerly the case.

The last table in this chapter showing the I.M.H.S. background of graduates entering the U. of I. gives the average number of credits earned bJ each class. This table serves only to substentiate further the comperisons which have already been made. For the purposes of Table 6 a credit is defined es a passing grade received upon the completion of a semester's study of a curriculum subject. Music, Physical Tducation, and R.O.T.C. service ere excluded, and Typing receives but one-half a creait.

\section{TABLE 6}

AVERAGE NUIBBER OF CREDITS RECEIVED IN I.M.H.S. BY GRADUATES ENTERING WHE U.OF I.

Year of Greduation from I.M.H.S.

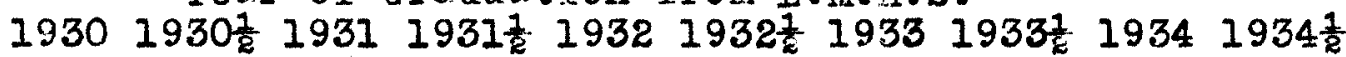

Average $\begin{array}{lllllllllll}\text { Number } & 34.7 & 34.2 & 34.2 & 33.7 & 33.9 & 33.3 & 33.5 & 33.2 & 32.8 & 33.3\end{array}$ of Credits

Eernea

The decrease in the average number of credits earned can be attributed to the chenge in curriculum from specialized 
courses to the present system of majors and minors. The former program of studies, in force until the fell of 1932, contained more required subjects than the present program of studies does, and hence the number of electives was small. Although the number of credits recuired for graduation, 32 , has not changed, it was not unusual for a student who was gradurted as late as 1932 to earn 35 or 36 credits in academic subjects.

Summary. The greatest number of graduates did not go to college, but of those who did, the total number attending the U. of I. was greater than the total number who attended other colleges. The percentages of the numbers attending the $U$. of I. had a spread of 14, while those attending other colleges had a spread of 17 , indicating a more constant attendance at the U. of I. The junior-senior averages and the I.Q. scores showed that the boys with the higher rating attended colleges other than the U. of I., but that the differences were not large. The high school averages and I.Q. scores of boys who did not enter college after graduation were significantly lower than those of boys entering the U. of $I$. The average rank of $U$. of $L$. enrollees was never lower than the fifth decile nor above the eeventh decile, a fact which indicates that they were above the rank of the average graduate. The 
graduates in $1934 \frac{1}{2}$ hed on average age which was as great as, or greater than, that of those in 1930. The change in the curriculum probably caused the decrease in the avergge number of credits earned in I.H.H.S. 


\section{Chapter IV}

THE COILEGE BACKGROUID OF 421 HIGH SCIOCI STUDENTS 


\section{Chapter III \\ THE COLLEGE BACKGROUND OF 421 \\ HIGH SCHOOI STUDENTS}

Historical Foreword. The University of Louisville is a municipel university founded in 1837. It became member of the Southern Association of Colleges and Secondary Schools in 1915, and was approved by the Association of American Univergities in 1936.

The Medical School, founded in 1837, has a national prominence, and until fairly recently it overshadowed the other schools of the Univereity. The school of Law wes founded in 1846, and the Iiberal arts College in 1907, at which time there were greduate students in the college. For three years there was a School of Public Health, which was discontinued. The School of Dentistry wels organized in 1918. The Summer School opened in 1922. The Speed School of Engineering was formed in 1925. The Division of ddult Education was added in 1928, and the Graduate school as such originated in 1929. The Louisville sunicipal College for Negroes wes put under the administration of the University in 1931. The School of Music was founded in 1932.

The College of Iiberal Arts of the University of Iouisvilie because of wise administration and etrong faculty 
has emerged from the shadow of the more prominent jedical School and is rapidly becoming nationally known by its new educationel policies. At the present time, 1938, there 8re 60 men and 15 women on the faculty of the college of Iiberal Arts of the University of Iouisville. Twenty-six men and 7 women are part time instructors, in the Division of fault Education and in other brenches of the University.

In 1929 the curriculum of the Iiberel hrts College was changed. The list of prescribed courses for entrance was modified so as to further more complete articuletion with recognized high school credits. This change wes preceded by a survey, which was mede by Dr. F. J. Kelly. The survey resulted in two recommendations, (I) closer articuletion of freshmen and sophomore years with the high school curriculum and (2) the introduction of survey courses in the first two years. In 1930, the Feculty of the Iiberal Arts College studied the objectives and organization of the college, and after approval by the Board of Trusteed, the orgenization was chenged in 1933 to what is known as the Junior-senior college Organization.

In The change was the more remarkable because the Iiberal Arts college of the University of Iouisville is a mediumsized, conservative, and financinlly restricted college. The

1. Oppenheimer, J. J., chapter XI of What About Survey Courses by Johnson, B. I., pp. 130-150 
college has changed redicaliy because the philosophy of the faculty has changed. The year 1930 had the further significance for the college for it saw (I) the estahlishment of the office of research secretary in the office of the dean of the college; (2) the wider use of cohievement tests in studying individurl students and in estimeting the effectiveness of instruction; (3) the encouragement of sone of the feculty to reoreanize esteblished courses toward functional ends. "Whe survey courses, which are the core of the junior college program, have this objective: to complete the general education of the secondery field by giving the student an overview of the nature of the modern world through better understanding of its physical and sociel natures. As established in the college they consist of, I. Inglish composition, II. Introduction to the study of Society, III. History of Civilizetion, IV. Survey of the Humanities, erd V. Survey of the Naturel sciences.

"vot only is the coliege reassured by the improvement of student achievement in the Junior college, but it is also proud of the fect that since the reorganization student mortality hes decreased from $54 \%$ to $36 \%$ in the five-year period.

"Whe issociete in arts degree is granted upon completion of sixty-one hours of credit and of the sophomore comprehensive exeminations. 
"The present policy provided for by the General curriculum follows this generel formula: (I) students of lower abilities will be sncourgged to remein in the college for two years provided they moke serious efforts and seem to be deriving some benefit from their college work; (2) students of average and better ability must sustain a standing of $\mathrm{C}$ or be penalized by being pleced on probstion or dropped ont of school; (3) after a student has been in residence for ono year and has not done satisfactory work he will be either placed in the General curriculum or will suffer some penalty under the scholarship rule; (4) students who are definitely placed on the General Curriculum will be advised not to take courbes which are definitely prerequisite to a major sequenco in the Senior college."

The determinetion of the collegiate background of the I.M.H.S. graduates at the U. of $I$. is best found through comparisons of scores on placement tests, the number of semesters in attendance, the college hours exrned the first, second, and fourth semesters, as well. as the totel number of hours, the quelity points geined during the same periods, the distribution of grades, and scores on sophomore achievement tests.

The placement tests yielded feirly large numbers, sufficient in most cases for comparisons. The exception was 
1930, when the number of cases was too meager to warrant comment. The tests in Contemporary Affeirs have been given only since 1936. The Language Tests are never given in terms of percentiles; the other tests are.

\section{TEBIE 7}

AVEREGES OF SCOFSE HADE BY I.IN.H.S. GRADUATES ON U.OT I. PIACEHENT TESTS, GIVEN BY PERCENIIIES

Placement Tests at Year of Greduation from I.M.H.S. U.Of I. No. \%-ile No. $p_{0}$-ile No. \%-ile No. \%-ile No. \%-ile

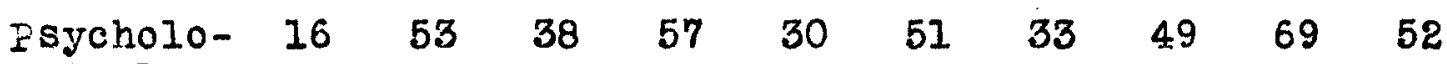
gical English $\begin{array}{llllllll}36 & 51 & 31 & 46 & 33 & 44 & 68 & 47\end{array}$ Reading $\begin{array}{llllll}31 & 55 & 33 & 49 & 68 & 56\end{array}$

\section{$1932 \frac{1}{2}$} $1932 \frac{1}{2} \quad 1933 \quad 1933 \frac{1}{2}$ 1933 1934

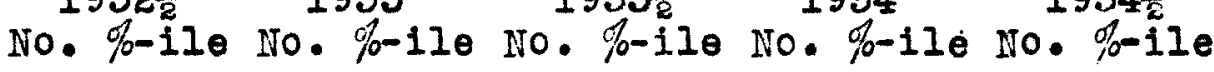
$1934 \frac{1}{2}$ Dsych. $35 \quad 47$ 41 49 29

63 67 54 $32 \quad 56$ Inglish $\begin{array}{lll}36 & 42 \quad 42\end{array}$ 44 31 62 67 51 Reading $\begin{array}{lll}33 & 49 & 40\end{array}$ 41 31 $\begin{array}{lll}61 & 67 & 47\end{array}$ $32 \quad 55$ 
only fairly noticeable correspondence between the I.M.H.S. average rank in the graduating class and scores on placement tests. The class of $1930 \frac{1}{2}$ had an average for all three tests above the average of most of the clesses. Table 2 indicates the high school average of the $1930 \frac{1}{2}$ class was below the scholastic average of most of the classes. The avergges of the class of 1931 were lower for all tests than the averages for most of the classes, but the scholastic average was above the scholastic average for most of the classes. The averages for the class of 1933를 were high both for the placement Tests and the scholastic average. The correspondence between the two criteria is only fairly good. The predictive value of Table 2 and Table 7 is not high.

We start with the average number of semester hours earned, to answer the question whether the first semester or the first year of college work is more difficult for the I.M.M.S. graduate at the J. of I. than the second year. The records at the U. of I. are complete in this respect, and in a form easy to use. The records for the first year (by semesters) show the number of hours that were earned by each boy who entered. Withdrawal during the first semester for whatever reason gives the graduate a total. of zero hours. The guidance as to which courses are to be taken or the number of courses attempted, has been disregarded, the records of semester hours governing the computations 
for sable 8. Witharawals vith possibility of passing bring down the totals, but for the purposes of comperison tena to be distributed over the eritire group.

\section{PBIE 8}

AVREAGS OH WHE TURBAR OF HOURE ERTED

THE PIRS YBR IN $2 \mathrm{HE}$ U. OP I. BY

I.M.H.S. GR. DUEMAS

Itumber

of Hours

Year of Gredustion from $\mathrm{L} \cdot \mathrm{H} \cdot \mathrm{H} \cdot \mathrm{S}$.

Earned No. LV. NO. Av. No. Av. No. Av. No. Ev.

Tirst

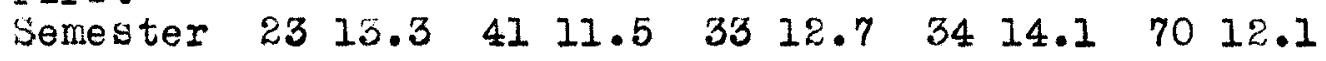

Second

Semester $20 \quad 13.1 \quad 35 \quad 12.6 \quad 31 \quad 12.0 \quad 29 \quad 13.5 \quad 5212.2$

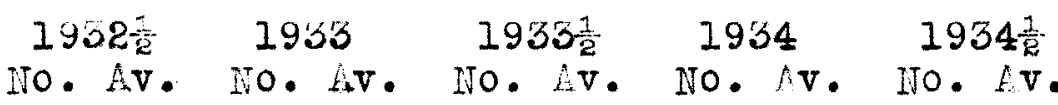

First

Semester $38 \quad 11.6 \quad 46 \quad 12.0 \quad 3111.7 \quad 7111.5 \quad 3414.0$

Second

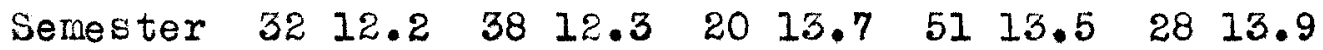

The first five classes during the first semester gained

a higher everage number of credits than the second five classes during the irst semester. The reverse of this condition wea true for the second semester. The individuel greduates may have elected \& aifferent number of hours and yet heve been 
successful in the number of hours taken. The date of Table 8 should not be used for prognostic purposes, but should serve only as an indicator of the range of hours earned. The average number of hours earned was larger the second semester than the first semester. The witharawals at the end of the first semester mey be the crusal factor. The erticulation between the data of mable 6 and the data of mable 8 appears to be slight. The number of credits earned in I.M.H.S. seems to be no criterion by which to predict the probable number of hours earned the first or second semesters at the U. of I.

The number of hours for the third semester was not taken, but the totel number for the four semesters wes averaged. The number of cases for the fourth semester and for the four semesters was less than the number in the previous table, and by the same token was more selective. Areater load might be carried, a measure, which as a prognostic factor, would be to some extent neutralized by the greater possibility of failure. The reduced number of cases indicates the mortality. 
TABLE 9

AVERAGES OY TEE IUUBER OF HOURS EARNED MHE FOURTH SEMESTRR IN THE U. OE I. BY I.M.H.S. GRADUATES

AND AVERAGES OF THE NOTAI NUABER OF HOURE EARNED IN FOUR SEUESPERS

Number Year of Graduetion from I.M.H.S. of Hours Earned 1930 $1930 \frac{1}{2}$ 1931 $1931 \frac{1}{2}$ 1932 NO. Av. NO. Av. HO. Av, NO. Av. NO. Av.

Fourth

Semester 17 14.2 $23^{13.9}$ $22 \frac{14.5}{60.5}$ $20 \stackrel{13.7}{ }$ $35 \quad 12.8$

During 56.6 59.4 57.8 52.6 Bour Semesters $\begin{array}{ccccc}1932 \frac{1}{2} & 1933 & 1933 \frac{1}{2} & 1934 & 1934 \frac{1}{2} \\ \text { NO. Av. NO. Av. NO. AV. NO. Av. NO. AV. }\end{array}$ Fourth Semester $20 \frac{13.2}{56.1} 24 \frac{13.3}{54.3} 13 \frac{13.4}{56.8}$ During Four Semesters

The first five classes earned a greater average number of hours during the fourth semester than did the second five classes. The general average for all classes was higher than the general average for either the first or second semester. The mortality was between forty and fifty per cent for tho number of students who enrolled and the number who completed four semesters. The establishment of the Junior-senior college Organization may reduce the mortality. The selectivity of 
the group completing four semesters tends to increase the average of semester hours earned. Since 120 hours are usually required for graduation, the averages for four semesters are fairly well up to normel expectency. The fact that the load is heavier the second yeer does not necessarily mean that the program is more difficult.

The averages of the quality points gained during the same periods as the semester hours earned will serve as onother basis of determining success of the graduates. Should the averages seem unusually low, it must be remembered that withdrawals while failing are given negative credit. The numbers of cases in each class are not given since they Ere identical with those of pable 8 . One quality point is awarded for each semester hour carried with the grade of $\mathrm{c}$, two quality points for each semester hour carried with the grade of $B$, etc.

\section{TABLE 10}

AVBRAGES OF THE IUURBER OF QULITY POINSS ERRNED THE PIRSM AITD SBCOND SEIESTERS BY I.M.H.S. GRADUATES AT SHE U. OF I.

Average

Number of Quality points Earned

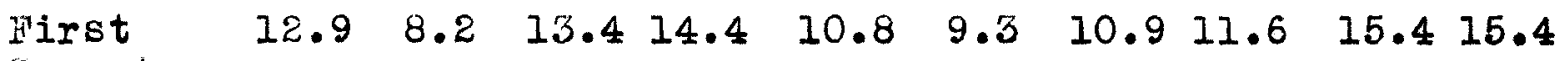
Semester

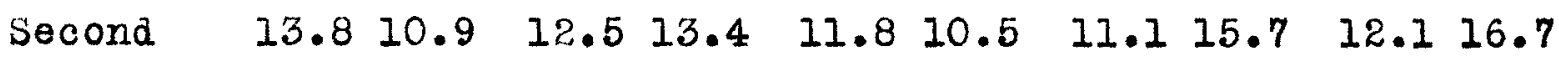
Semester 
Seven of the ten clesses geined more quality points the second semester than they did the first semester. A comperison of rable 8 with Fable 10 indicates the fect that there is no pattern for the ten classes. The average number of semester hours does not seem indicative of the everege number of quelity points. This condition preveils for the second semester. The heavier loed cerried the second semester is probebly responsible for the grester number of ouslity points esried the second semester. The number of witharswals $2 t$ the end of the first senester mey have had some effect.

The etfect of witharawels cen be seen by the everages of the qualty points for the iourth senester and for the four sewesters. The logd for the fourth semester was hegvier than the load for either the first or second semester. The number of coses is the sene $c s$ the rumoer of ceses in mole 9.

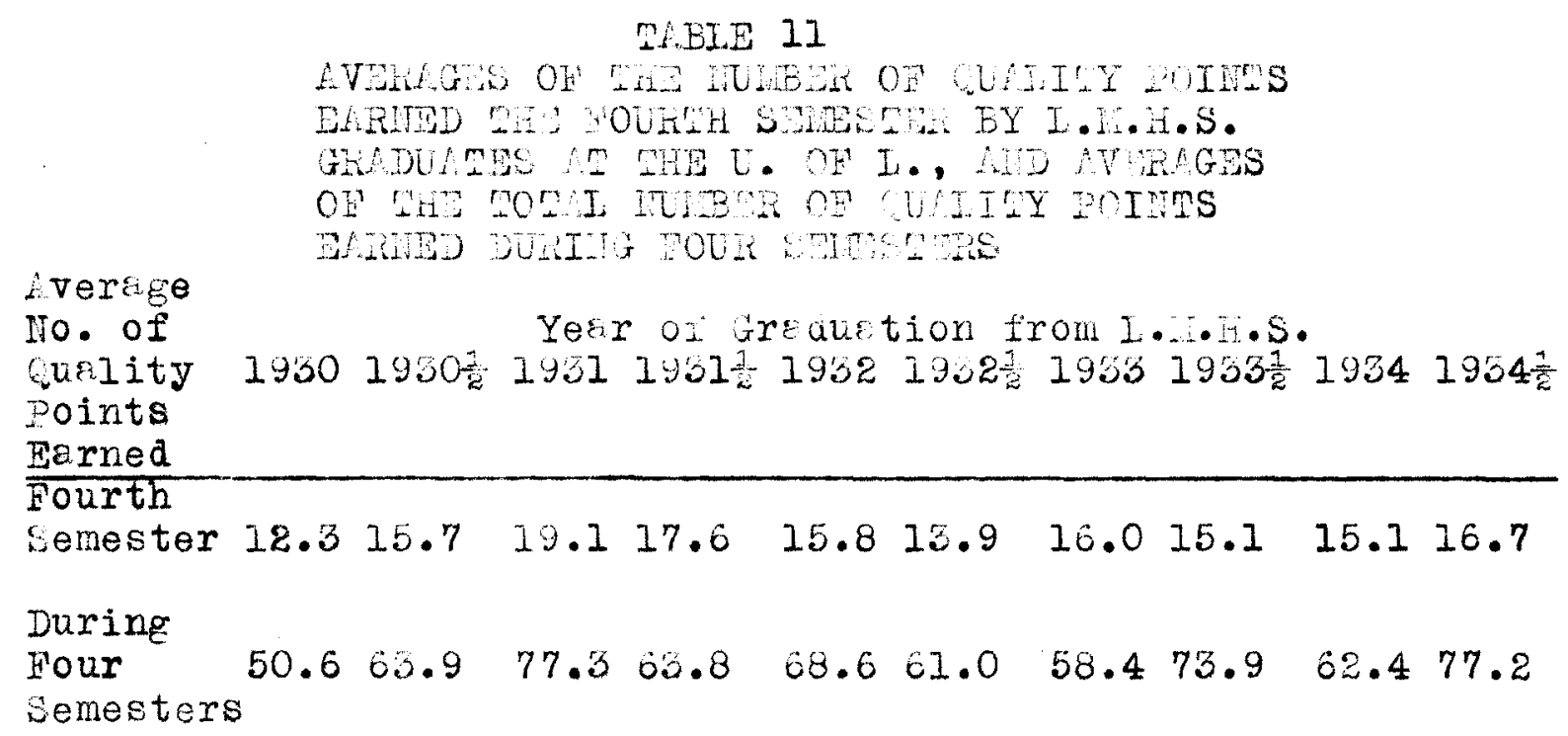


Eight classes had a higher average in quality points the fourth semester then they did the first semester, and the adrantage over the second semester was seven to two. since this was also true of the averages of semester hours, we may aay that the heavier the load the greater the number of quality points. The majority of classes had a larger number of quality points for four semesters than they had semester hours. The evergges for the four semesters seemed extraordinary, but upon rechecking the data, it then appeared peculiar that they were not higher, for when students gain as many as 217 . 196, 187, or 183 quality points in four semesters, the averages must indeed be low of some.

The success of the average I.K.H.S. graduate at the U. of I. may be indicated by a combination of the number of semester hours earned with the number of cuality points gained. This combination is made by quality points standings, which are obtained by dividing the number of quality points by the number of semester hours. 


\section{TABIE 12}

QURIITY POINT STANDING OF I.M.H.S. GRADUAMES

AT THE U. OF I. THE TIRST, SECOND, FOURTH, AIJI) TOMAI OF FOUR SEMESTERS

Semester

et the

$\mathrm{T}$. of $\mathrm{I} \cdot \mathrm{Ho}$

Quality 1

$1930 \frac{2}{2}$

No. St.

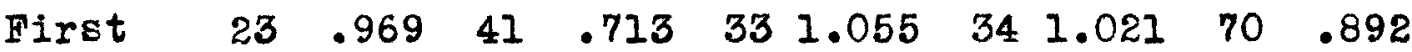

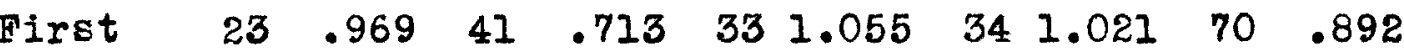

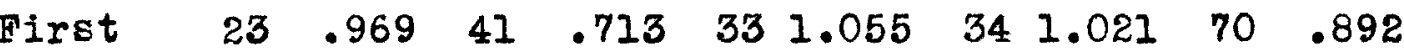
St. of $I$ 1931

.M.H.S. Greds. 1931 i 1932 $\begin{array}{lllllllllll}\text { Second } & 20 & 1.053 & 35 & .865 & 31 & 1.417 & 29 & .993 & 52 & .967\end{array}$

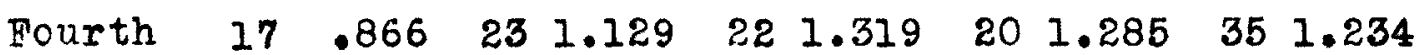

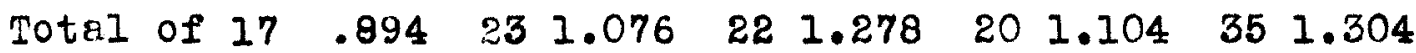
Four

$\begin{array}{ccccc}1932 \frac{1}{2} & 1933 & 1933 \frac{1}{2} & 1934 & 1934 \frac{1}{2} \\ \text { No. St. No. St. No. St. No. St. No. St. }\end{array}$

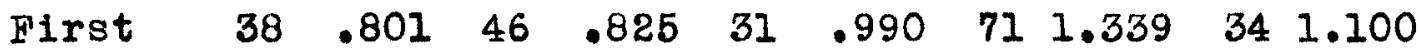
$\begin{array}{lllllllllll}\text { Second } & 32 & .861 & 38 & .903 & 20 & 1.146 & 51 & .897 & 28 & 1.202\end{array}$

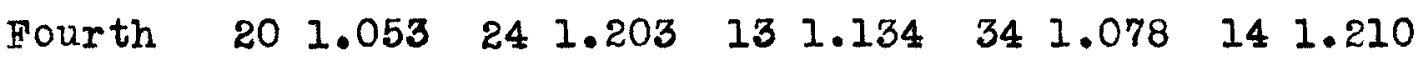
$\begin{array}{lllllllllll}\text { Totel of } & 20 & 1.087 & 24 & 1.075 & 13 & 1.301 & 34 & 1.070 & 14 & 1.343\end{array}$ Four

The data of mable 1 . Indicate the foct thet four classea attained a $C$ averege, thet is, a quality point standing of 1.0 , the first semester; four, the second semester; nine, the fourth semester; and nine, the total of four semesters. Right classes had higher standing the second semester than they had the first semester. Eight classes had e higher standing the fourth semester than they had the first semester. Seven classas had a 
higher stonding the fourth semester then they hed the second sewester. Since .80 ard 1.4 are tgken as the limits of the second quertile et the U. of I., the dete show ore cless (1930 $\left.\frac{1}{2}\right)$ vith $\varepsilon$ uality point stending in the lowest quertile the Iirst semester. Il other quity point stenaings ere in the second quertile.

The verges of unity points ma semeter hours show the success of the rversge student but a not indicrte corresporiderice between I.H.H.s. gredes cid the U. of I. grodes. The

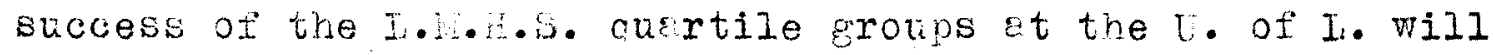
be shom by their aistribution eccording to quelity point stending a dulty point standing is obteined by dividing the number of cuality points grined by the number of semester hours expred. The two uprer qurtiles of E.H.t. greduetes receive grade fveriges from $85 \%$ to $100 \%$

\section{MPIE 13}

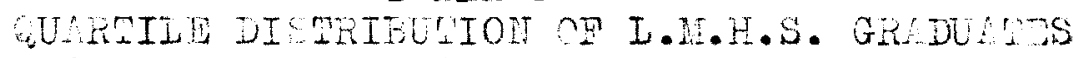

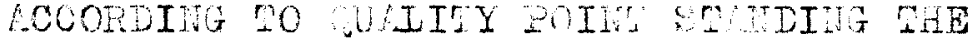

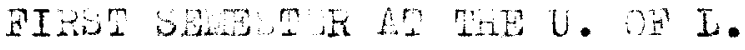

Gurtile velity point stending at $i$. of L. the Hirst Senester et 2 or above $2-1$ - $1-0$ Negetive rotel I.W.H.S. MO. \% MO. \% HO. \% NO. \% No. go

$\begin{array}{lrrrrrrrrrr}\text { Fourth } & 24 & 6 & 25 & 6 & 1 & & 1 & & 51 & 12 \\ \text { Third } & 12 & 3 & 35 & 8 & 17 & 4 & 2 & & 66 & 15 \\ \text { Second } & 1 & & 57 & 13 & 96 & 23 & 30 & 7 & 184 & 43 \\ \text { First } & 1 & & 12 & 3 & 50 & 12 & 57 & 13 & 120 & 28 \\ \text { Total } & 38 & 9 & 129 & 30 & 164 & 39 & 90 & 20 & 421 & 100\end{array}$


The deta of Table 13 indicete that 38 atteined a cuality point stending of 2 or above, 36 of whom had 8 echolastic average of $85 \%$ or above. Two graduates, whose scholastic Everage wa: below $85 \%$, ettained a collegiste stending of $B$ or better. Ninety had a failing collegiate average, and of this number only 3 had a scholestic average of $85 \%$ or better.

Thirty per cent had a quelity point stending of $c$, $14 \%$ of whom had a scholastic avere ef $85 \%$ or better, and $16 \%$ an average below $85 \%$. Thirty-nine per cent averaged $D$ in the T. of I., 4\% of whom averaged $85 \%$ or gbove ir I.M.H.S., and $35 \%$ averaged $85 \%$ or above.

Fifty-one students were in the highest quartile at I.M.H.S. only two of whom had \& curlity point standing of less then $C$ at the $U$. of $I$. Fifteen per cent were in the third quertile, $11 \%$ of whom attained $\mathrm{C}$ or better. Forty-three per cent were in the third quartile, $30 \%$ of whom gained a gualty point standing of less than $c$. Wenty-eight per cent were in the lowest quertile at the I.M.I.S., 25\% of whom had a collegiate average of less then 0 .

Theoretically, 811 boys mo failed at the U. of I. would be expected to come from the loreft quartile at the I.M.M.S. Night oer cent of the foilures, hoveror, were from other quertiles. The divisions of the gredustes by quartiles ard by quelity point standings are not similar, and the degree of 
correspondence is not shown by this table. Mable 13 has a fair predictive value.

\section{YBIE 14}

IUUABER OF CHANCES IN 100, OH I. F.H.S.

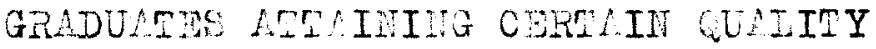

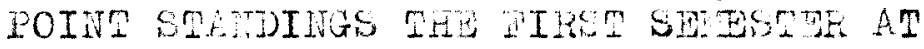

THE U. OF I.

Quertile e.t

I.I.I. in.
Chences in 100 of Gredustes attrining ruality point steridings

\& or above $2-1 \quad 2-0$ Ifegative

Fourth

47

49

2

2

Third

18

53

26

3

Second

First
31

10
52

42
.5

16.5

1

A gredurte in the fourth quertile at I.M...S. has 47

chances in 100 of atteining an everege of $B$ or above st the U. oI I., and he hes 96 chences in 100 of ettainirg en averge of $\mathrm{C}$ or bbove. A greduste in the third quertile has 71 chences in 100 of atteining en verege of $\mathrm{C}$ or cbove, and 26 chences of heving a $D$ average. $f$ gredurte in the second quertile has one chance in 200 of attining an average of $B$ or above, 31.5 chances in 100 of atteining an Everage of $c$ or Ebove, and 16.5 chances ir 100 of feiling. A graduate in the lowest quertile hes almost on equel chence to feil as he hes to pass. A boy ebove the second quertile has 73 chences in 100 of atteining an average of $\mathrm{C}$ or above. A boy below the third 
quartile has 79 chences in 100 of heving on average below $\mathrm{C}$.

The distribution of the graduates according to the number of semesters in attendance may enswer the question as

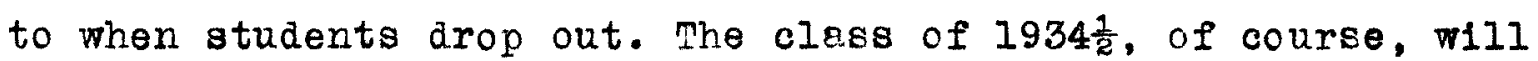
not graduate till Januery, 1939. The deta were taken in the suamer of 1937, the effect of which fact would be to allow the cless of $1934 \frac{1}{2}$ an opportunity to attend the U. of I. five

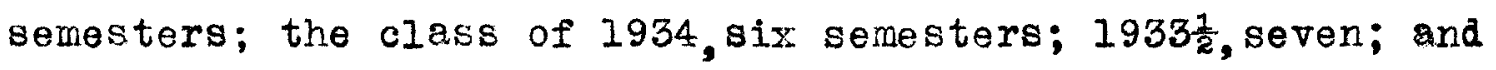
the class of 1933 would have been the last class with sufficient time to complete eight semesters. 
TABLE 15

QUERTILE DISTRIBUTION OF I.M.H.S. GRADUATES

ACCORDING IO NUMBTR OF SEMESTERS ENROLISD AT

THE U. OF I.

No. Quar-

Year of Graduation from L.M.H.S.

Sem. tile

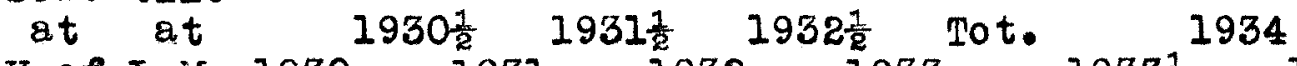

$\begin{array}{lllllll}\text { U.Of I.M. } & 1930 & 1931 & 1932 & 1933 & 1933 \frac{1}{2} & 1934 \frac{1}{2}\end{array}$

I. H.S.

\begin{tabular}{|c|c|c|c|c|c|c|c|c|c|c|c|c|}
\hline 8 & $\begin{array}{l}4 \text { th } \\
\text { 3rd } \\
\text { 2nd } \\
\text { lat } \\
\text { Tot. }\end{array}$ & $\begin{array}{l}2 \\
2 \\
5\end{array}$ & $\begin{array}{l}2 \\
1 \\
3 \\
2 \\
8\end{array}$ & $\begin{array}{l}3 \\
4 \\
4 \\
1 \\
8\end{array}$ & $\begin{array}{l}2 \\
2 \\
1 \\
2 \\
7\end{array}$ & $\begin{array}{l}3 \\
1\end{array}$ & $\begin{array}{l}2 \\
4 \\
2 \\
1 \\
9\end{array}$ & $\begin{array}{l}1 \\
3\end{array}$ & $\begin{array}{r}15 \\
8 \\
13 \\
8 \\
44\end{array}$ & $\begin{array}{l}- \\
- \\
- \\
-\end{array}$ & $\begin{array}{l}- \\
- \\
-\end{array}$ & $\begin{array}{l}\overline{-} \\
\overline{-} \\
\text { - }\end{array}$ \\
\hline 7 & $\begin{array}{l}\text { 4th } \\
\text { 3rd } \\
\text { 2nd } \\
\text { lst } \\
\text { Tot. }\end{array}$ & & $\begin{array}{l}1 \\
1 \\
2\end{array}$ & $\begin{array}{l}1 \\
1\end{array}$ & $\begin{array}{l}1 \\
1\end{array}$ & 1 & & $\begin{array}{l}1 \\
1\end{array}$ & $\begin{array}{l}3 \\
3 \\
6\end{array}$ & $\begin{array}{l}4 \\
2\end{array}$ & & \\
\hline 6 & $\begin{array}{l}\text { 4th } \\
\text { 3rd } \\
\text { 2nd } \\
\text { lst } \\
\text { Tot. }\end{array}$ & $\begin{array}{l}3 \\
4\end{array}$ & $\begin{array}{l}1 \\
2 \\
3\end{array}$ & $\begin{array}{l}1 \\
2 \\
3 \\
1 \\
7\end{array}$ & $\begin{array}{l}1 \\
3 \\
4 \\
1 \\
9\end{array}$ & $\begin{array}{r}4 \\
6 \\
5 \\
2 \\
17\end{array}$ & $\begin{array}{l}2 \\
1\end{array}$ & $\begin{array}{l}7 \\
8\end{array}$ & $\begin{array}{r}7 \\
14 \\
21 \\
9 \\
51\end{array}$ & $\begin{array}{l}1 \\
2 \\
3\end{array}$ & $\begin{array}{r}4 \\
7 \\
10 \\
21\end{array}$ & \\
\hline 5 & $\begin{array}{l}4 \text { th } \\
\text { 3rd } \\
\text { 2nd } \\
\text { lst } \\
\text { Tot. }\end{array}$ & $\begin{array}{l}1 \\
2 \\
3\end{array}$ & $\begin{array}{l}4 \\
1 \\
5\end{array}$ & $\begin{array}{l}1 \\
1\end{array}$ & $\begin{array}{l}2 \\
2\end{array}$ & $\begin{array}{l}1 \\
1 \\
1\end{array}$ & $\begin{array}{l}1 \\
1 \\
1 \\
3\end{array}$ & $\begin{array}{l}2 \\
1 \\
4\end{array}$ & $\begin{array}{r}2 \\
2 \\
9 \\
8 \\
21\end{array}$ & 1 & $\begin{array}{l}1 \\
3 \\
4\end{array}$ & $\begin{array}{l}2 \\
3 \\
1 \\
6\end{array}$ \\
\hline 4 & $\begin{array}{l}\text { 4th } \\
\text { 3rd } \\
\text { 2nd } \\
\text { Ist } \\
\text { rot. }\end{array}$ & $\begin{array}{l}1 \\
3 \\
1 \\
5\end{array}$ & $\begin{array}{l}3 \\
1 \\
4\end{array}$ & $\begin{array}{l}3 \\
5\end{array}$ & $\begin{array}{l}2 \\
3\end{array}$ & $\begin{array}{l}1 \\
4 \\
3 \\
8\end{array}$ & $\begin{array}{l}3 \\
1 \\
4\end{array}$ & $\begin{array}{l}1 \\
2 \\
2 \\
3 \\
8\end{array}$ & $\begin{array}{r}4 \\
4 \\
15 \\
14 \\
37\end{array}$ & $\begin{array}{l}1 \\
1\end{array}$ & $\begin{array}{l}I \\
4 \\
3 \\
8\end{array}$ & $\begin{array}{l}4 \\
2 \\
1 \\
1 \\
8\end{array}$ \\
\hline 3 & $\begin{array}{l}\text { 4th } \\
\text { 3rd } \\
\text { 2nd } \\
\text { lst } \\
\text { Tot. }\end{array}$ & 1 & $\begin{array}{l}1 \\
2 \\
3\end{array}$ & $\begin{array}{l}2 \\
1 \\
3\end{array}$ & $\begin{array}{l}1 \\
1 \\
3 \\
1 \\
6\end{array}$ & $\begin{array}{l}4 \\
5 \\
9\end{array}$ & $\begin{array}{l}4 \\
4 \\
8\end{array}$ & $\begin{array}{l}3 \\
1 \\
4\end{array}$ & $\begin{array}{r}1 \\
1 \\
18 \\
14 \\
34\end{array}$ & $\begin{array}{l}1 \\
2 \\
4\end{array}$ & $\begin{array}{l}1 \\
2 \\
3\end{array}$ & $\begin{array}{l}1 \\
2 \\
3 \\
1 \\
7\end{array}$ \\
\hline 2 & $\begin{array}{l}\text { 4th } \\
\text { 3rd } \\
\text { 2nd } \\
\text { lst } \\
\text { Tot. }\end{array}$ & $\begin{array}{l}2 \\
2\end{array}$ & $\begin{array}{r}4 \\
6 \\
10\end{array}$ & $\begin{array}{l}1 \\
5 \\
6\end{array}$ & $\begin{array}{l}1 \\
3\end{array}$ & $\begin{array}{r}8 \\
1 \\
10\end{array}$ & $\begin{array}{l}3 \\
3 \\
6\end{array}$ & $\begin{array}{r}3 \\
7 \\
10\end{array}$ & $\begin{array}{r}1 \\
1 \\
22 \\
24 \\
48\end{array}$ & $\begin{array}{l}I \\
I \\
2\end{array}$ & $\begin{array}{r}1 \\
2 \\
9 \\
2 \\
14\end{array}$ & $\begin{array}{l}3 \\
4\end{array}$ \\
\hline 1 & $\begin{array}{l}4 \text { th } \\
\text { 3rd } \\
\text { 2nd } \\
\text { lst } \\
\text { Tot. } \\
\text { al }\end{array}$ & $\begin{array}{r}3 \\
3 \\
23\end{array}$ & $\begin{array}{r}1 \\
3 \\
2 \\
6 \\
41\end{array}$ & $\begin{array}{r}2 \\
2 \\
33\end{array}$ & $\frac{2}{34}$ & $\begin{array}{r}1 \\
9 \\
8 \\
18 \\
10\end{array}$ & $\begin{array}{r}4 \\
1 \\
5 \\
38\end{array}$ & $\begin{array}{r}3 \\
5 \\
8 \\
46\end{array}$ & $\begin{array}{r}2 \\
21 \\
21 \\
44 \\
285\end{array}$ & $\begin{array}{r}1 \\
1 \\
7 \\
2 \\
11 \\
31\end{array}$ & $\begin{array}{r}1 \\
3 \\
11 \\
6 \\
21 \\
11\end{array}$ & $\begin{array}{l}1 \\
3 \\
2 \\
6 \\
34\end{array}$ \\
\hline
\end{tabular}


Table 15 shows that I.K.H.S. students of the third and fourth quartiles tend to remain in the $U$. of $I$. longer than do the pupils of the first and second quartiles. In the classes studied, the boys of the first quartile dropped out in large numbers the first term, and, in succooding terms, continued to dron out by large percentages, though the numbers decreased as the groups grew smaller. Thirty-one students out of the total number of 120 of the first quartile remeined one term only; 26 remeined two; 19, three; 15, four. At the same time out of a total number of 184, the second quartile lost, also in decreasing numbers, 42, 37, 23, and 20. No such scheme appeared in the losses from the third and fourth quartiles, the numbers running $7,3,3,11$ for the students of the third quartile and 2, 3, 3, 9 for students of the fourth out of totel numbers of 66 and 51, respectively. Seventeen of the total number who remeined in the U. of I. four terms or less, were from the fourth quartile, 28 from the third, 122 from the second, and 91 from the first. While approximately 4.7 times as many students from the first and second quartiles es from the third and fourth remeined two years or less, the percentages from the lower quertiles were greater in proportion during the first, second, and third terms than were percentages of losses from the upper quartiles. 
The first and second quartiles lost the following numbers: 73 of the total of 82 students remaining only one term, or approximately eight times as many students as were lost by the third and fourth quertiles; 63 of the 73 remaining two termo, a Iittle more than six times es many; 42 of the 48 remaining three terms, about six times as many; but only 35 of the 55 remaining four terms, just one end three-fourths times as many. The dropping out of a larger percentage of lower than of upper cuartile students confirms what we should expect.

The percentage of I.M.H.S. students remaining two jears or less tends to increase. a study of the numbers remaining one year or less indicates an irregular trend for the first six classes, then a consistently large loss from each of the last four clesses. In the first class studied, 1930, 5 out of 23 students, approximately $22 \%$, remained at the U. of I.

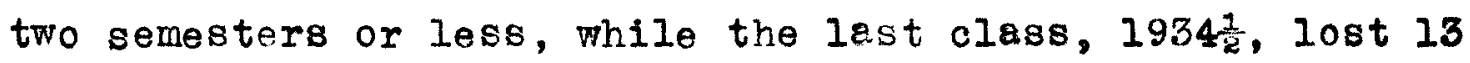

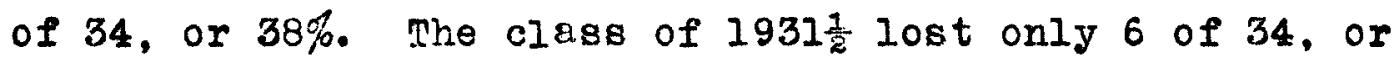
$18 \%$; but the classes of $1933 \frac{1}{2}$ and 193410 st 15 of 31 , or $48 \%$, and 35 of 71 , or $49 \%$, respectively.

The tendency for student mortality to increase in recent years is seen again in the figures for four terms. The class of 1930, by the end of the sophomore year, lost 11 of 23 students, or $48 \%$ of the total; the class of $1934 \frac{1}{2}$ lost 28 of 
34, or $82 \%$. Other classes showed losses as low as 44\%, or 15

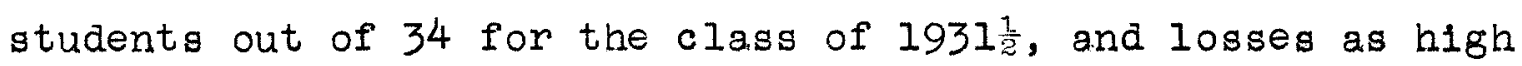
as $67 \%$, or 21 students out of 31 , for $1933 \frac{1}{2}$, the class that showed the percentage next to the highest figure, that of $82 \%$ in $1934 \frac{1}{2}$. L.M.H.S. does not have as great a chance of success as formerly, as far as duration of stay is concerned.

The increasing losses during the first and second years may be accounted for by a variety of factors. One cause not to be overlooked is the possible effect of the reorganization of the high school curriculum, which took place in 1932 , permitting a student to graduate from high school with majors and minors largely of his own choosing as opposed to the former method of a prescribed college preparatory course. Another posalble explanation may be found in the stricter grading in college in recent years. Still another reason may be an economic one and may have some connection with the fact that the majority of L.M.H.S. boys are enrolled in high school in the R.O.T.C. unit and are outfitted with uniforms, shirts, and caps. This aid may make the burden of outfitting themselves in college an increasingly difficult one for L.M.H.S. graduates. Causes intangible as well as tangible play a part in the success of students in college. The chances are that the combination of causes differs greatly for individuals. 
The most thet can be done here is to show wat chances the average boy, or better still, the student in each of the I.M.H.S. graduating quartiles, has for success in the U. of I. Table 16 and mable 17, based on Table 15, show by totals in quartile ranking, more clearly than can mable 15 show by years, the chances of success that graduates will heve as measured by length of stry. The figures for Table 16 were complled from seven I.M.H.S. greduating clesses, 1930 through 1933, and included 285 atudents enrolled at the U. of I. for eight semesters or less.

\section{TLBLE 16}

NUIBBER OF CHANCES IN 100 OF I.H.H.S. GRADUATES REMAIIING ONE TO PIGHT SEZMETERS AT THE U. OF I. BASED ON IENGTE OT STAY AT THE U. OF I. OF 286 STUDEITS IN SEVIN GRADUAMING CLLSSES FROM 1930 THROUGH 1933

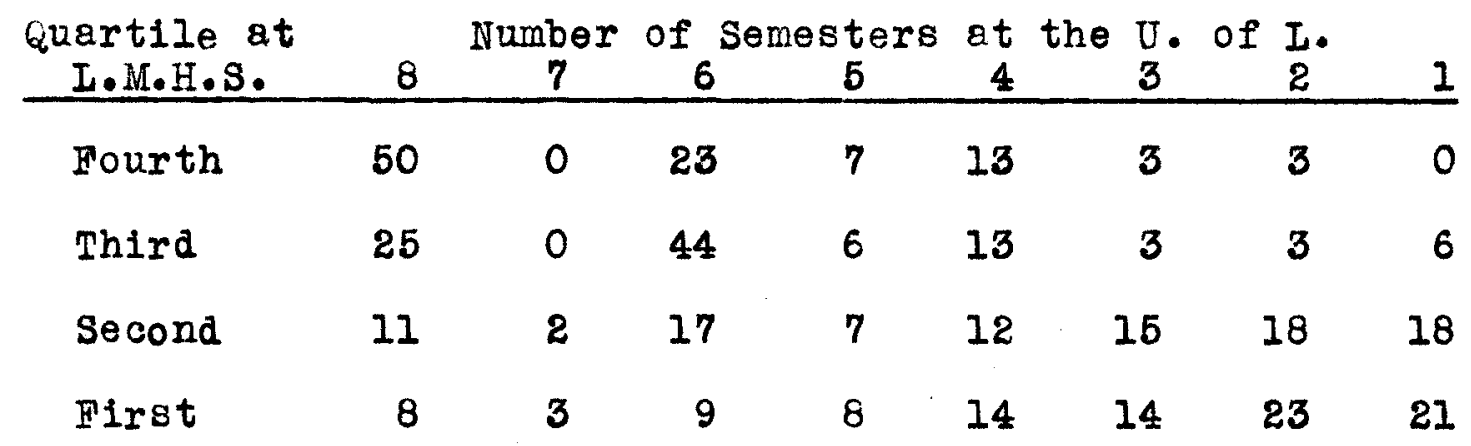

Table 16 indicates that graduates of the third and fourth quartiles, who enter their fourth year at the U. of I., are 
not likely to arop out during the senior year but will continue through the eighth gemester. The chances are that only 2 in 100 of the second quartile and 3 in 100 of the first quartile who reach the seventh semester will fail to continue. The figures regarding the lower quartiles may seem unusuelly small, but the fact must be borne in mind that the mortality of students of the two lower quartiles is very heavy in the freshman and sophomore years.

I. M.H.S. graduates of the fourth ruartile heve 50 chences in 100 of completing eight semesters and 73 chances in 100 of completing six semesters. Compared to fourth quartile students, only one-half as many students of the third quartile are Iikely to remein eight semesters, although 69 in 100 of the third quartile will complete their junior year, almost as large a percentage as for the fourth quartile. students of the second quartile have 11 chances in 100 of completing eight semesters, that is, less than one-helf as many chances as students of the third quartile and less than one-fourth as many chances as students of the fourth quertile. Students of the first cuartile have 8 chances in 100 of remaining through the senior year, or less then one-third as many chancer as graduates of the third quartile and less than one-sixth as many chances as graduetes of the fourth quartile. 
The chences are that no graduete of the top quartile will drop out at the end of his first semester and only 6 out of 100 of the third quartile will feil to continue, but 18 out of 100 and 21 out of 100 of the second and first quartiles, respectively, will feil to complete more than one semester. The chances are that comparatively few I.H.H.S. graduetes of the upper quartiles will drop out at the end of the first or even the second year, while a noticeably large number of the lower quertiles will not survive. The chances are that only 3 of 100 in the fourth quertile will stop at the end of the first year, and 19 of 100 at the end of the second year. Students of the third quartile will likely lose 9 of 100 at the end of the first yeir, and 25 of 100 at the end of the second. on the other hand, 36 of 100 students of the second quartile will be lost the first yerr, and 63 of 100 the second, while 44 of 100 of the first quertile will go the first year and 72 of 100 the second.

TABIE 17

IUUIBEA OF CHUCES IN 100 OF I.M.H.S. GEADULPES

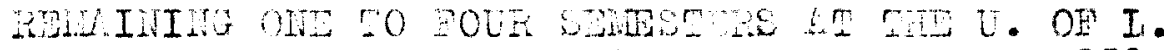

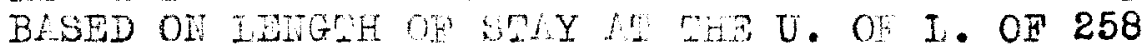

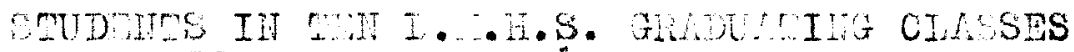
YYON 1930 HEOUGH 2934

Quertile at Number of semesters at the U. of I.

\begin{tabular}{lrrrr} 
I.I.H.S. & 4 & 3 & 2 & 1 \\
\hline Fourth & 53 & 18 & 18 & 11 \\
Third & 39 & 11 & 25 & 25 \\
Eecond & 17 & 19 & 30 & 34 \\
First & 16 & 21 & 29 & 34
\end{tabular}


Table 17 indicates, according to quartile ranking, the chances thet L.h.H. greanetes heve of remaining at the U. of I. through four semesters. The figures were compiled from ten I.H.H.S. gredueting classes, 1930 through 1934 a total of 258 students enrolled at the $U$. of $I$. for four semesters or less. Toble 17 shows more clearly than could pable 15 the fact that the chances are distinctly in favor of students of the upper quartiles remeining at the $U$. of $I$. a longer time than do students of the lower quartiles. Students of the fourth quertile have 53 chences in 100 of rempining four semesters and just 11 cherices in 100 of dropping out after one term. Boys of the first quartile, on the other hand, have just 16 chances in 100 of remeining four terms and 34 chances in 100 of remaining only one semester. Chences for the second quartile are remerkably similar to those of the first. Thirty-four students in 100 are likely to remin one semester and only 17 four semesters. Students of the third quartile are more likely to remain four terms then ere studente of the lower quartiles; in fact, the former have more then twice as mony chences of remeining two full years.

Sophomore Comprehensive Mests are administered upon the completion of the fourth semester for purposes of predicting future success in light of past performances. During some years the data were numerous for some particular tests but meager for 
others. The avereges in mable 18 gre given in percentiles, which are comparetive with national percentiles for the years of 1932-1934 inclusive. A percentile of 63 during this period indicates that such in avergge was 13 percentiles above the average for the nation's liberal frts colleges, tested. The variations in the numbers tested are caused by subsequent tosting of some who omitted certein tests. Other students did not take these tests because of wi tharewel.

\section{M $\cap$ BIE 18}

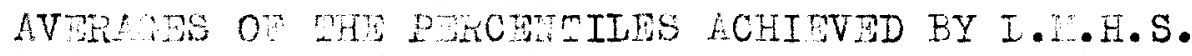

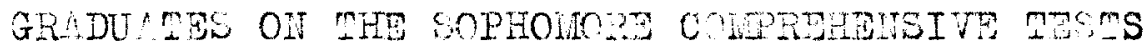

$$
\text { A. WHE U. OF I. }
$$

Sophomore CompreYear of Gradurtion from I.H.t.S. hensive $19301930 \frac{1}{2} 1931 \quad 1931 \frac{\frac{1}{2}}{2} 1932$

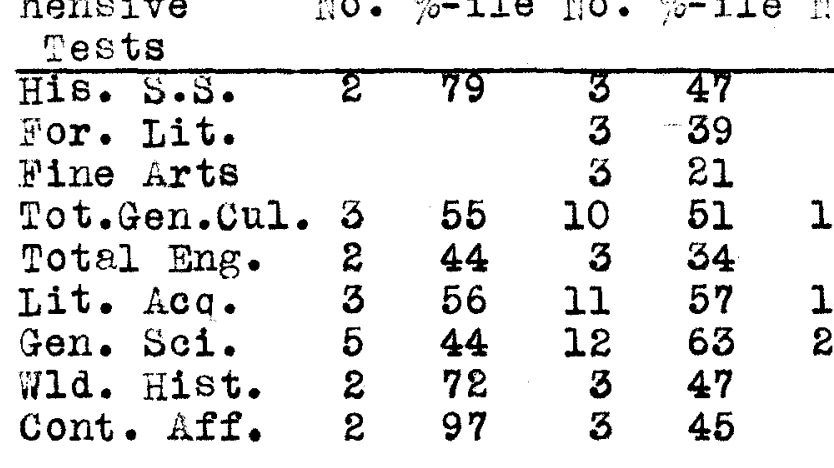
$1932 \frac{1}{2}$ 1933 $1933 \frac{1}{2}$ $\begin{array}{lllll}50 & 14 & 59 & 27 & 65\end{array}$ $\begin{array}{lllll}58 & 6 & 44 & 6 & 73\end{array}$

263

$\begin{array}{lllll}63 & 7 & 49 & 6 & 65\end{array}$
$2 \quad 27$ 628 54 675

\begin{tabular}{|c|c|c|c|c|c|c|c|c|c|c|}
\hline & No & $\begin{array}{l}32 \frac{1}{2} \\
\%-i 1 \theta\end{array}$ & & $\begin{array}{l}33 \\
\%-11 e\end{array}$ & No. & $\begin{array}{l}33 \frac{1}{2} \\
\%-i l e\end{array}$ & $\begin{array}{r}1 \\
\text { No. }\end{array}$ & $\begin{array}{l}34 \\
\%-11 \theta\end{array}$ & & $\begin{array}{l}34 \frac{1}{2} \\
\%-11 \theta\end{array}$ \\
\hline His. S.S. & 12 & 60 & $I 1$ & 65 & 11 & 83 & 28 & 71 & 12 & 80 \\
\hline For. Int. & 8 & 64 & 17 & 60 & 11 & 65 & 28 & 84 & 12 & 75 \\
\hline Fine Arts & 8 & 74 & 17 & 60 & 11 & 55 & 29 & 58 & 12 & 67 \\
\hline Tot.Gen.Cul & 8 & 65 & 17 & 63 & 11 & 72 & 28 & 69 & 12 & 79 \\
\hline Total Eng. & 12 & 51 & 17 & 50 & 10 & 56 & 28 & 51 & 12 & 59 \\
\hline Iit. Act. & 8 & 58 & 17 & 50 & 10 & 48 & 29 & 54 & 12 & 61 \\
\hline Gen. Sci. & 11 & 70 & 17 & 54 & 10 & 66 & 27 & 65 & 12 & 63 \\
\hline ld. Hist. & 10 & 53 & 17 & 50 & 10 & 71 & 29 & 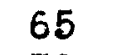 & 12 & 75 \\
\hline Cont & 12 & 76 & 17 & 62 & 10 & 77 & 29 & 79 & 12 & 78 \\
\hline
\end{tabular}


The results are plessine for they compre very fevorebly with the netional percertiles on these tests. In particuler the clesses of 1934 and 1932 were outstanding, for each had but one average below the sixtieth percentile, the one being Norld History in 1932, and potel English in 1954. The avereges for Generil Science seened very high throughout the last nine classes. Whe averages for contemporery Affeirs were well above the fiftieth percentile, as were the verages for goreign literature. Whe highest averege for more then ter cases was 84 in Foreign Iitereture in 1934. More students vere tested in the later clesses, and there seens to be a higher average. Sumriery: The scores inede by I.M.H.S. greduates on the U. of I. Placemert Dests corresponded roughly with high school grades when averages ot the two measures were taken. Tho graductes were epproximetely four percentile points above the median for all tests. The svereges of the hours earned the first, second, and fourth semesters indicated thet $\&$ hesvier schedule was carried in succossive semesters. Withdrowe. of weaker stuajents was pobably the resson for \& higher averege of quality points goined in succossive semesters by students who remained at the U. of $I$. The data indicated the fect that students who attended the U. of $I$. four semesters obteined a quelity point standing of 1.0 or better, with the exception of the class of 1930. With this single exception all I.M.H.S. clesses showed a quelity point stending of 1 plus for four 
semesters. Data indicated the fact that I.M.H.S. boys attending the $U$. of $I$. four semesters have verying chances of acquiring the quality point standing of their graduating classes. At the two extremes were students of the fourth quartile with 47 chences in 100 of attaining a cuality point standing better than their class and students of the first quartile with 89 chances in 100 of showing a standing lower then that of their class. Chances of showing the class standing of between 1.0 and 2.0 were as follow for the different quartilea: fourth, 49 chances in 100; third, 53 in 100; second, 31 in 100; first, 10 in 100. The fact that third quartile students showed 53 in 100 as compared to 49 in 100 for fourth quartile students of reaching the clase averege may be explained by the fact that the third quartile showed only 18 in 100 as compared with 47 in 100 for the fourth quartile of atteining s standing higher than thet of their class.

Students of the upper two quartiles tended to remain in the $U$. of $I$. a longer time than did students of the lower quartiles. Data showed that the total percentages of students remaining one year or less and also the percentages remaining two jegrs or less tended to increase with the passing of jears. Figures according to quertile ranking indicated whet might have been expected. Chances of success as measured by duration of 
time spent at the U. of $I$. are greatest for the fourth quartile, the third, second, and first auartiles following in the order named. Students of the fourth quartile showed a better than even chance of staying four semesters and an even chance of stgying eight semesters. On the other hand, students of the first quartile showed only 16 chances in 100 of steying four semesters and 8 chances in 100 of staying eight semesters. Chances of the second quartile were but slightly better than those of the first quartile. Chances of the third quartile were better than twice those of the second, and one-half those of the fourth.

The scores of the sophomore Comprehensive Tests from 1931

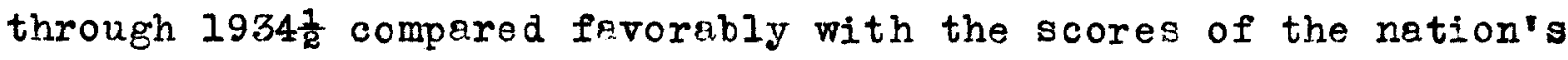
liberal arts colleges. The U. of L. scores in practically every case were substantially above the national median. 
Chapter V

DISTRIBUTION OF GRADES AID

COMPARISON OP QUARTILES 


\section{Chapter $\nabla$ \\ DIETRIBUTION OF GRADES AND COMPÉRISON \\ OF UARTILES}

The traitional measurement of success in school

Whether it be elementary, secondary, or on the college level, is by scholastic grades. Try as some educetors will, the fact remains that the juagment of the instructor, though it may be subjective in nature, is the best criterion we haverof the success of the student. The hours of credit, and to greater degree the quality points, depend upon grades in college. We shall consider the correspondence or non-correspondence of grades received in high school with grades received in college, how the grades are distributed, and the combination of grades end subject fields.

No attempt will be made to find the relation between grades and the instructor who awarded the grades. All grades will be given equal weight nothwithstanding the instructor or his peculiarities of grading.

The U, of $L$. uges the system of greding on the normal distribution curve. The five grades $A, B, C, D$, and $F$ are used, the letter $\mathrm{F}$ representing the failing grede. The variations of the everages as compiled in the tables on cuality points might be expleined by a scrutiny of the figures in the following tables. The percenteges of the numbers ere given rather then 
the total numbers themselves, for percentages may be used more easily in comparisons. The relation of grades made by I.W.H.S. graduates to the gredes mede by the entire College mey indicate the success of the I.M.H.S. student.

\section{TABI: 19}

PERCTINAGES OF I.IA.H.S. GRADURTES ACCORDING TO THE GRADES RECEIVED THE TIRST YEAR $\triangle O$ THE U. OF I. AND THE SAIE PLECTITAGES POR THE BIIIIR COLIEGE

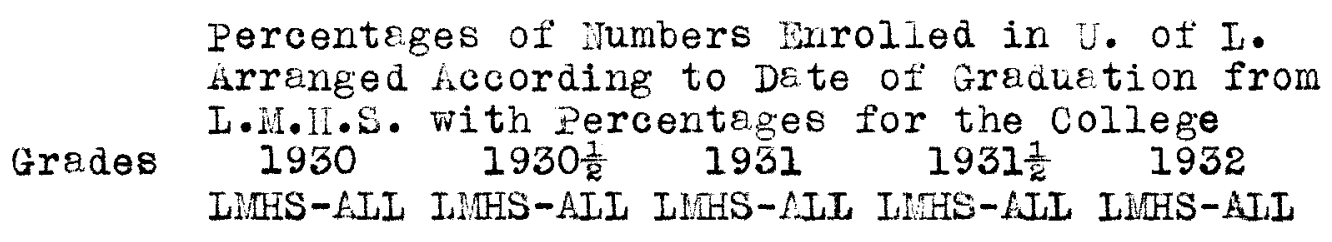

$\begin{array}{rrrrrrrrrrr}\mathrm{A} & 5 & 11 & 6 & 11 & 13 & 11 & 3 & 9 & 11 & 9 \\ \mathrm{~B} & 20 & 25 & 16 & 26 & 17 & 26 & 26 & 26 & 14 & 26 \\ \mathrm{C} & 45 & 33 & 40 & 36 & 35 & 36 & 38 & 37 & 39 & 37 \\ \mathrm{D} & 25 & 18 & 25 & 16 & 17 & 16 & 23 & 17 & 24 & 17 \\ \mathrm{~F} & 5 & 13 & 12 & 9 & 18 & 9 & 10 & 11 & 12 & 11\end{array}$

$\begin{array}{lllll}1932 \frac{1}{2} & 1933 & 1933 \frac{1}{2} & 1934 & 1934 \frac{1}{2}\end{array}$
IMHS-NII INHS-AIL LHHS-NII, LIHS-NTI, JMHS-AII

$\begin{array}{rrrrrrrrrrr}\mathrm{L} & 8 & 10 & 1 & 10 & 15 & 10 & 4 & 10 & 7 & 10 \\ \mathrm{~B} & 15 & 28 & 19 & 28 & 15 & 27 & 19 & 27 & 20 & 28 \\ \mathrm{C} & 38 & 37 & 47 & 37 & 38 & 39 & 43 & 39 & 49 & 41 \\ \mathrm{D} & 27 & 15 & 22 & 15 & 23 & 14 & 25 & 14 & 23 & 13 \\ \mathrm{~F} & 12 & 10 & 11 & 10 & 9 & 10 & 9 & 10 & 1 & 9\end{array}$

A fairly well brianced distribution seems to exist for the five gredes for I.A. . . E. greduetes during the five yeare, although a lorger percentage received D's then $B^{\prime} s$ and a larger 
percentage failed than received A's. Seven classes from I.M.H.S. received a lower percentage of $B^{\prime} s$ than the entire College received. Eight clesses received a higher percentage of C's than the entire College, and the other two classes were but one percentage point lower. Each of the classes received a higher percentege of $D^{\prime} s$ than did the entire College, and the difference was from 6 percentage points in

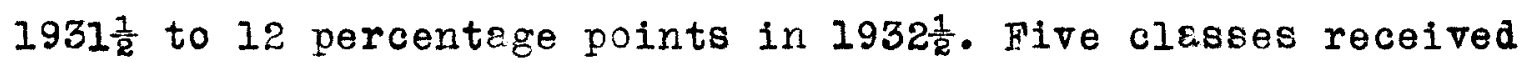
a higher percentage of $F^{\prime} s$, and the sane number received lower percentage of F's than the entire college received. It appears that the failures are fairly constent in comperison, but that I.M.H.S. graduates succeed at a lower leveI then the entire college.

The effect of withdrawals unon the distribution of the grades may be seen by a comparison of the grades of I.M.H.S. graductes with the grades for the entire college during the second year. 
TABLE 20

PETCENTAGES OF I.M.H.S. GETDURTES ACCORDING

TO IHE GRIDES RECEIVED THE SECOND YEIR AT

THE U. OF I., AND THE SAUE PRRCENTAGES FOR

THE HNIRE COLIEGE

Percentages Enrolled in U. of $I$. Arranged by Date of Graduation from I.M.H.S. with percentages for the College

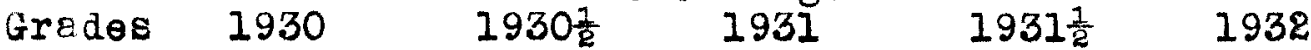

IMHS-ALI ILES-AII LNHS-ALI IMHS-AII IMHS-ALI

$\begin{array}{rrrrrrrrrrr}\mathrm{A} & 1 & 11 & 7 & 9 & 16 & 9 & 9 & 10 & 8 & 10 \\ \mathrm{~B} & 25 & 26 & 11 & 26 & 27 & 26 & 24 & 28 & 23 & 28 \\ \mathrm{C} & 50 & 36 & 44 & 37 & 31 & 37 & 38 & 37 & 39 & 37 \\ \mathrm{D} & 17 & 16 & 29 & 17 & 23 & 17 & 23 & 15 & 22 & 15 \\ \mathrm{~F} & 8 & 9 & 8 & 10 & 2 & 10 & 6 & 10 & 8 & 10\end{array}$

$\begin{array}{ccccc}1932 \frac{1}{2} & 1933 & 1933 \frac{1}{2} & 1934 & 1934 \frac{1}{2} \\ \text { LWHS-AII } & \text { IMHS-AII } & \text { LWHS-AII } & \text { INHAS-AII } & \text { LNIHS-AII }\end{array}$

$\begin{array}{rrrrrrrrrrr}\mathrm{A} & 7 & 10 & 5 & 10 & 14 & 10 & 6 & 10 & 7 & 11 \\ \mathrm{~B} & 22 & 27 & 30 & 27 & 17 & 28 & 25 & 28 & 26 & 29 \\ \mathrm{C} & 44 & 40 & 37 & 39 & 40 & 41 & 47 & 41 & 41 & 40 \\ \mathrm{D} & 21 & 22 & 21 & 14 & 22 & 13 & 18 & 13 & 21 & 12 \\ \mathrm{~F} & 5 & 7 & 7 & 10 & 7 & 9 & 4 & 9 & 4 & 8\end{array}$

The percentages of failures for I.H.H.S. graduates were smaller for the second year then they were for the first year. The percentages of A's were about the same for both years. The entire College had $20 \%$ more A's than I.M.H.S. graduates had for the five years. Whe entire college had $36 \%$ more B's than I.H.H.S. graduetes had for the five years. L.M.H.S. graductes hed $63 \%$ more $D^{\prime} s$ than the entire college. The entire College had $33 \%$ more F's than the I.M.H.S. graduates. Each of the ten classes hed a lower percentage of F's than the entire 
College. Each of the ten classes had a higher percentage of D's than the entire college. The more striking features were the small percentages of feilures, the incresse in percentages of $B^{\prime} s$, and the decrease in the percentages of $D^{\prime} s$ of the second year in comparison with the first.

We shall consider now the grades translated into quality points according to quartile distriblition. In Table 21 the divisions of the quality points were made from a consideration of (1) the grade divisions (2) the number of gradurtes who received a negative number of quality points (3) the number of semester hours carried normally and (4) the fact that an upper group, \& lower group, and two middle groups separate the graduates into groups of comparable numbers. The two unper quartiles of I.H.H.S. graduates, as stated before, receive grade avergges from $85 \%$ to $100 \%$. These graduates are recommended to college by the principal. The following table can be used for observing the articuletion between high school averages and colleglate greder. An examinetion of the quartiles might indicate the success of the four groups. 
TABIE 21

QUARTIIE DIETRIBUTIOI OF QUAIITY POIITS

RECEIVED BY I.M.H.S. GRADUATES THE FIRST

SEMESTER AT MHE U. OF I.

No. cuar-

Qual. tile

Pts. at

at I.M.

U.Of H.S. $2930 \frac{1}{2} \quad 1931 \frac{1}{2} \quad 1932 \frac{1}{2} \quad 1933 \frac{1}{2} \quad 1934 \frac{1}{2}$

I. by $1930 \quad 1931 \quad 1932 \quad 1933 \quad 1934$ Total Schol. Av.

$\begin{array}{llllllllllll}\text { than } 1 \text { 2nd } & 1 & 5 & 1 & 3 & 6 & 4 & 1 & 6 & 10 & 1 & 38\end{array}$

\begin{tabular}{rrrrrrrrrrrrr} 
& lst & 2 & 7 & 6 & 6 & 12 & 6 & 9 & 2 & 9 & 2 & 61 \\
\hline \multirow{2}{*}{$1-15$} & 4th & & & & & & & & & 1 & & 1 \\
& 3rd & 1 & & & 1 & 2 & 2 & 1 & 2 & 3 & 7 & 19 \\
& 2nd & & 9 & 5 & 6 & 22 & 11 & 12 & 6 & 20 & 10 & 101 \\
& 1 st & 8 & 8 & 7 & 2 & 7 & 5 & 5 & 3 & 2 & 1 & 48 \\
\hline \multirow{2}{*}{$15-30$} & 4 th & & & 3 & 3 & 3 & 1 & 3 & 4 & 4 & 2 & 23 \\
& 3rd & & 1 & 1 & 5 & 6 & 1 & & 3 & 10 & 4 & 31 \\
& 2nd & 5 & 5 & 4 & 4 & 3 & 4 & 9 & & 7 & 2 & 43 \\
& 1 ist & 2 & 2 & 2 & 1 & & & 2 & 1 & & & 10 \\
\hline \multirow{3}{*}{30} & 4th & & 2 & 3 & 2 & 6 & 1 & 2 & 3 & 1 & 5 & 25 \\
3nd & 3rd & 2 & 1 & 1 & 1 & 3 & 3 & 1 & 1 & 1 & & 14 \\
More & Ist & 1 & & & & & & & & & & 1 \\
\hline
\end{tabular}

In ten graduating classes one boy of the highest quartile in I.M.H.S. dropped to the failing group at the U. of I. Two boys of the third quartile dropped as low as the friling group at the U. of I. Fifty boys renked in the highest quartile at I.M.H.S., of whom 48 were divided almost equelly between the C group end B or better group et the U. OI I. Two boys of the third quartile at I.l.i.s.s. aropped as low as the failing group 
at the $U$. of I. Fourteen of the third quartile were ranked in the $B$ or better group at the U. Of I. The majority of the third quartile were divided between the $D$ group and the $C$ group at the U. of $I_{.}$, more being clessified in the $\mathrm{C}$ groun then in the $D$ group. One boy who ranked in the second quertile ot I. I. H.S. achleved the $B$ or better group at $U$. of $I$. , one hundred one maintained the same group number, and of those, in the second quertile more increased their group number standing than lowered it at the $U$. of $I$. one hundred twenty-one graduates ranked in the lowest quartile et I.H.H.S., sixty-one of whom ranked in the failing group at the $U$. of $I$. , and sixty improved their standing, ten to the $C$ group and two to the $B$ or better group.

Inveriably more students remeined in the like numbered group in the U. of I. in which they were ranked at I.M.H.S., then changed their grouping, but the differerce is small enough to raise the question whether the degree of correspondence is sufficient to have meaning. The predictive value of this table is in conseguence rether low.

We may diccover more about the sticcess of the various groups of I.I.H. S. graduetes if we consider the number of quality points earred during four semesters at the $U$. of I. The study of a teble of distribution by quartiles of the graduates may indicate the reliebility of de thich has been 
given reviously. In Table 22 the compiletion of quelity points was bosed on (1) the number of hours carried by the everage graducte ond (2) the number of cuelity points awarded for tho various grades.

\section{TABIE 22}

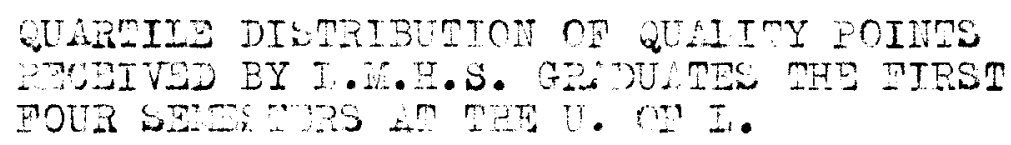

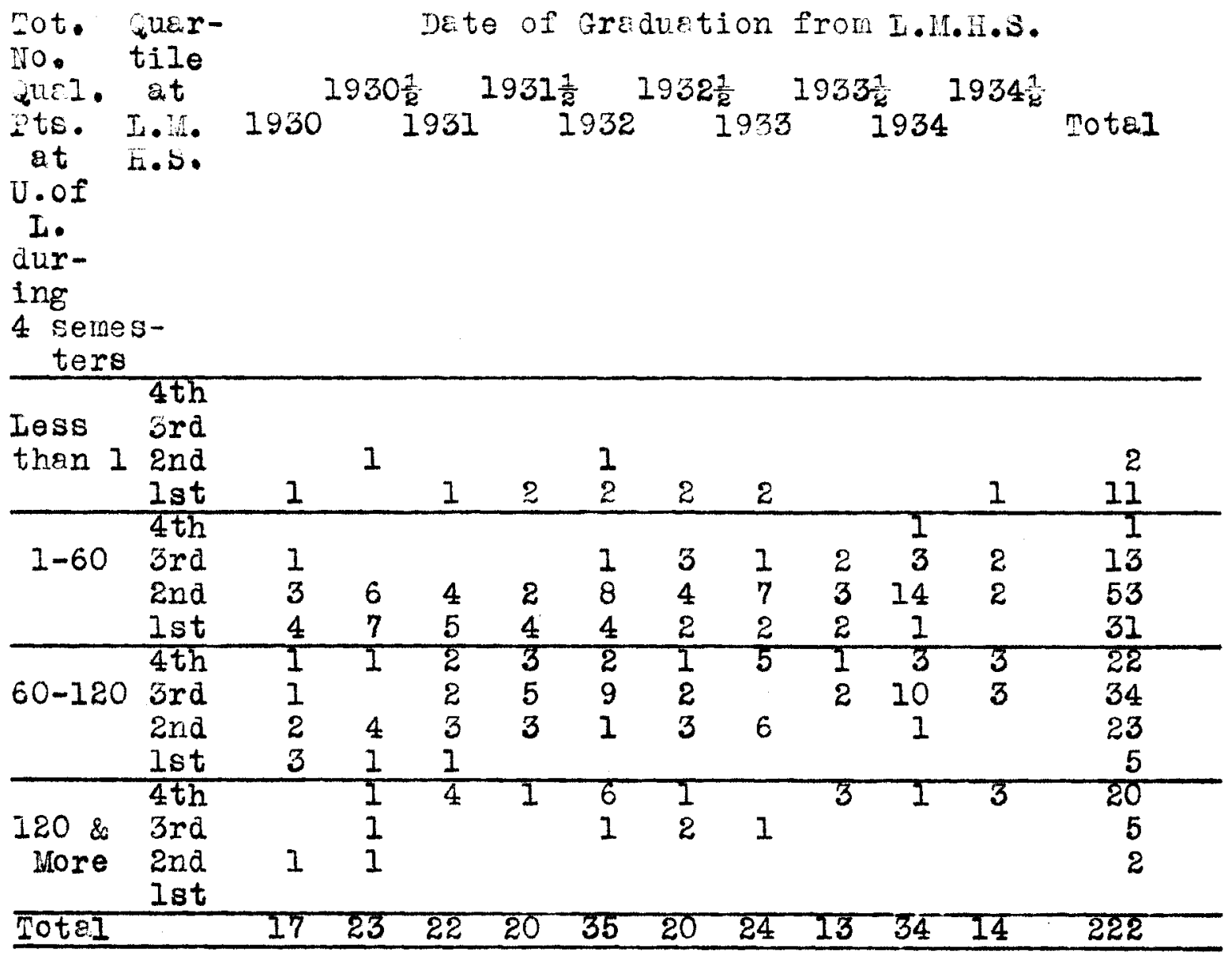

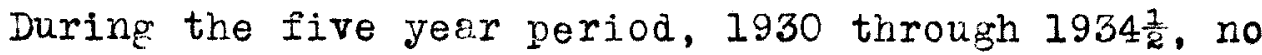
I.H.H.S. graduate in the third or fourth quartile dropped as low as the failing group et the $U$. of I. Thirteen of 222 
students, or $6 \%$, were in the filing group. Ininety-eight of 222, or 44\%, grined from 1 to 60 quality points. Eighty-four of 222, or 38\%, gained from 60 to 120 quelity points. Fwentyseven of 222, or 12\%, gained more than 120 quelity points. One graduate of the fourth quertile earned less than 60 quality points. The forty-three graduotes in the fourth quartile were almost evenly divided between the two highest groups. The chences are 98 in 100 thet graduete in the fourth quartile will gein 60 or more cuelity points during the first four semesters the U. of I. Fifty-two gredurtes were in the third quartile, and 34 , or $65 \%$, of these gained from 60 to 120 quality points. The chences ere 75 in 100 thet a graduate in the third quartile will gain 60 or more quelity points in four semesters. Eighty graductes were in the second quartile, and the chances are 69 in 100 of a graduate in the second quertile geining less then 60 quelity points. Forty-seven graduates were in the first cuertile, and the chances are 89 in 100 of a graduete in the first quertile geining less than 60 quality points. A greduate in the first quartile has no chonce of geining more then 120 quality points.

A comparison of the tables of cuelity points for one semester and for four semesters, Fable 21 and Teble 22, indicates thet the numbers in the higher two quartiles wero 
more constant than the numbers in the lower two quartiles. in better comparison of the tenure of certain groups might be made by quartiles arranged according to grodes received in I.M.H.S. Fifty of the highest quartile in I.M.I.S. remained one semester, 42 of whom stayed four semesters. Fifty-one of 66 boys in the second highest quartile were in attendance at the end of four semesters. Seventy-nine of 190 boys in the second quartile received quality points for four semesters. Forty-seven of 116 students who were in the lowest cuertile stayed four semesters.

Tobles 21 and 22 create on impression that there is some relationship between grades received in I.M.H.S. and those received in the $U$. of $I$. Correletion coefficients might help to check this impression. According to explanations of coefficients of correlation there should be a certain number of caser before the degree of relationship can be ascertained. A smell number of cases would indicate only that relationship is present without showing the degree. The tebles which follow should indicate in either case the valldity of the aforementioned impression. 


\section{$T A B I E 23$}

CORPEILITION BETWEEN GRADES RECEIVED IN I.W.H.S. AND GRADES RECEIVED THE FIRST SEMESTER AT MHE U. OF I.

Year of Greduation from I.M.H.S.

$19301930 \frac{1}{2} 1931 \quad 1931 \frac{1}{2} 19321932 \frac{1}{2} 1933 \quad 1933 \frac{1}{2} 19341934 \frac{1}{2}$

Coeff1-

cient

of $\quad .526 .564 \quad .736 .741 \quad .753 .709 \quad .561 .803 \quad .564 .639$ $\operatorname{corr} \theta-$

lation

(r)

P.E. $(x) .102 .077 \quad .061 .102 \quad .050 .056 \quad .073 .050 \quad .058 .072$

No. of

$\begin{array}{lllllllllll}\text { Cases } & 23 & 41 & 33 & 31 & 70 & 38 & 45 & 31 & 71 & 34\end{array}$

The data from Table 23 indicate that there is a definite reletionship between the grades (shown by quality points) for the first semester at the U. of $I$. and the averages of the grades received in the junior and senior years in I.M.H.S. The classes of 1932 and 1934 had a sufficient number of cases to confirm this statement. The probable errors of the coefficients of correlation are small enough to conform to what has been said. The correlption for the entire group is .660 with a probable error of .070. There seens to be predictive value in the grades in I.M.H.S. for success in the U. of $I_{\text {. The data }}$ of Table 23 is strengthened by the data of Table 13.

The number of I.M.H.S. graduates in attendance for four 
semesters is less than the number of graduates in attendance for one semester, but the number is sufficient to show whether any relationship is present.

\section{TABLE 24}

CORKELI TION BETWERN GRADES RECEIVED IN

I.H.H.S. AND GRADES RTCEIVED FCP FOUR

SDMESTRS AT THE U. OF I.

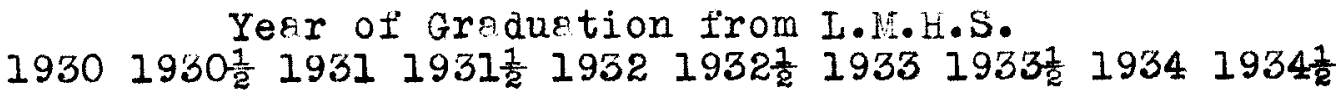

Coeffi-

cient

$\begin{array}{llllllllllllll}\text { of } & .463 & .584 & .666 & .795 & .669 & .682 & .720 & .367 & .664 & .428\end{array}$ $\operatorname{corre-}$

lation

$(\mathrm{r})$

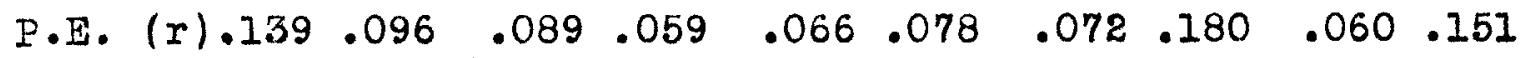

No. of

Cases

$17 \quad 23$

$22 \quad 22$

3420

$24 \quad 12$

$34 \quad 14$

The data of Trble 24 indicete that $\varepsilon$ positive relationship exists between grades in L.M.H.S. and grades, shown by quality points, received for four semesters at the U. of I. The coefficierit of correletion should be at least four timea the probable error of the coefficient of correletion to show thet some relationship is present. Seven classes conform to this standard, a fact which is sufficient to substanticte the 
statement that there is relationship between the two criteria. Table 24 has some predictive value though less than that of Table 23 .

Summary . A comparison of grades for L.M.H.S. graduatea with grades for the entire College for the first year indicated a skew toward the lower grades. A correction of this was made the second year, particularly in regard to the F's, where the skew was in the opposite direction. The percentages of $\mathrm{C}^{\prime} \mathrm{s}$ were higher for both years for I.M.H.S. graduates than for the entire college, and the same was true for $D^{\prime} \mathrm{s}$. The percentages of $A^{\prime} \mathrm{g}$ and $B^{\prime} \mathrm{s}$ was lower for I.M. $\mathrm{I} . \mathrm{S}$. graduates than for the entire College.

A consideration of the grades, shown by quality points, received by L.M.H.S. graduates, grouped into quartiles, Indicated that the highest group received the highest grades; the second highest group, the second highest grades;etc. The grades received for four gemesters confirm this belief. The data indicate that a student who receives a low average at L.M.H.S. Will receive a low average at the U. of $I$. We may say this with more assurance than we may say that a student with a high average at L.M.H.S. Will receive a high average at the U. of I.

L.H.H.S. graduates who were ranked in the bighest quartile were inclined to rank in a lower group at the U. of I. This was true of the graduates in the third quartile after they had been in the $U$. of $L$. for two years. The graduates who 
were ranked in the lowest quartile at the I.w.H.S. tended to be in either the $D$ group or the failing group. This wes true at the ena of one semester and was still true at the end of two years. The correlation was fair, but the predictive value of the tebles was not very high. The data of mable 13 seems to substantiate this statement. 


\section{Chapter VI}

CCIPARISON OT ITENS FRCMI L.M.H.S. RICORDS WICI CRITERIS FROM THE

U. OR I. KBCORDS 
Chapter VI

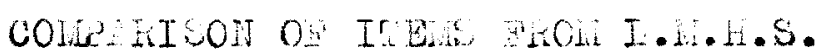

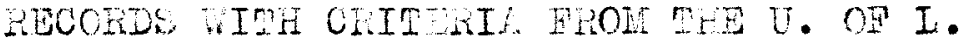
ReCords

The comperisons of the scholestic avereges of the

members of ten clesses greduf ted from I.H.H.S. Who heve entered the $U$. of $I_{1}$. heve shown certein cheracteristics which now shall be combined. The best wethoo of expressing relationship is by merns of coefficients of correletion, but in some situgtions the number of cases is too smell to use that me thod. The consideration of the distribution of two criteria may be sufficient for the purposes of this study. In some of the tables the total group is used, for the possibility of greater significance which should not be ninimized. In order that results worthy of comment may be resched, the reletionship between parts of the afta which epply to the grestest number in both I.M.H.S. and the U. of I. has been computed. Since we are meing a stetistics study of greduates from the I.H.H.S., the records for age, rank in gredueting class, average grade for junior and senior work, occupetion of parent, and number of credits received in verious subject fields of the high school curriculum constitute the first of the two criteris. The selection of a criterion in the college with which to compere the high school records was difficult 
to make. Plocement tests were elimingted because a sufficient number of graduates did not take them. The same situation was true for the sophomore tests. The number of semesters in attenäance was given for each graduate, but the last three classes have not had the opportunity of completing eight semesters. The number of hours earned the first semester was seriously considered as the best criterion, but there were objections since the number of hours earned (I) gives no credit for grades higher than D, (2) compares only passing and failing without qualifying pessing, and (3) tokes no account of differences in student lodds due to such fectors as employment and limitation by faculty.

The one fector in the collegiate setup which has none of the objectionable features of the records just mentioned is the number of quelity points earned the first semester. Every student who enrolls in the $U$. of $I$. is credited with the number of quelity points geinea. For those who withdraw before the completion of the first semecter, or for those who fail the lerger part of their courses, a zero number or a negative number of quality points is recorded. Therefore, the number of quality points earned the Iirst semester constitutes the second of the two criterie.

The quality points have been clessified into four groups. 
The highest group corresponds to grades of $B$ and above, the second group corresponds to a grade of $\mathrm{C}$, the third group to a grade of $D$, and the lowest group to a grade of $F$ or a failing grade. These groups may be considered as quartiles to correspond by number with the high school cuartile division.

The question of the effect of age upon the success of students in college has been mentjoned in chapter II, and the relationship of age to success in college will be considered now. Tables were constructed for each of the ten classes from 1930 to 1934 $\frac{1}{2}$, but the paucity of deta invalidated any conclusions which might have been arawn. Four hunared twenty-one greductes hed records of their ages. Percentages were computed to the nearest unit. The following table is for the purpose of determining whether there is any predictive velue in the age of graduates at the date of groduation, with respect to probrble success in the U. of $I$. (See Teble 25 on page 78) Seventy-one per cent of L.X.H.S. graduates who attended the U. of I. were between the gges of 16 and 19 at the date of their graduation. Nineteen per cent vere unusually old or unusually young at the date of graduation.

One boy, of a total of 74 boys, over 18 years of age attained the highest group at the U. of I. at the end of the first semester, and he was in the highest quartile at I.M.H.S. 
MABLE 25

DTRCAITSGES AND IUIERTS OF L.H.H.S. GRADUATES SEPARA IED LCCORDITG TO LGRS IT DATE OF GRADUASION NUD CILSSIEIND BY THE HUHERR OF GUAIITY

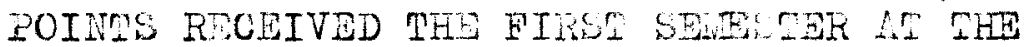

$$
\text { U. OF } I_{\text {. }}
$$

Age in uer- Number of uelity Points Barned tho Years at tile First semester at the $U$. of $I$. Dete of at Iess than Gradua- L.j. 30 and over $15-301-15,1$ Total tion from H.S. No. $\%$ No. $\%$ No. $\%$ No. $\%$ No. $\%$ I.M.H.S.

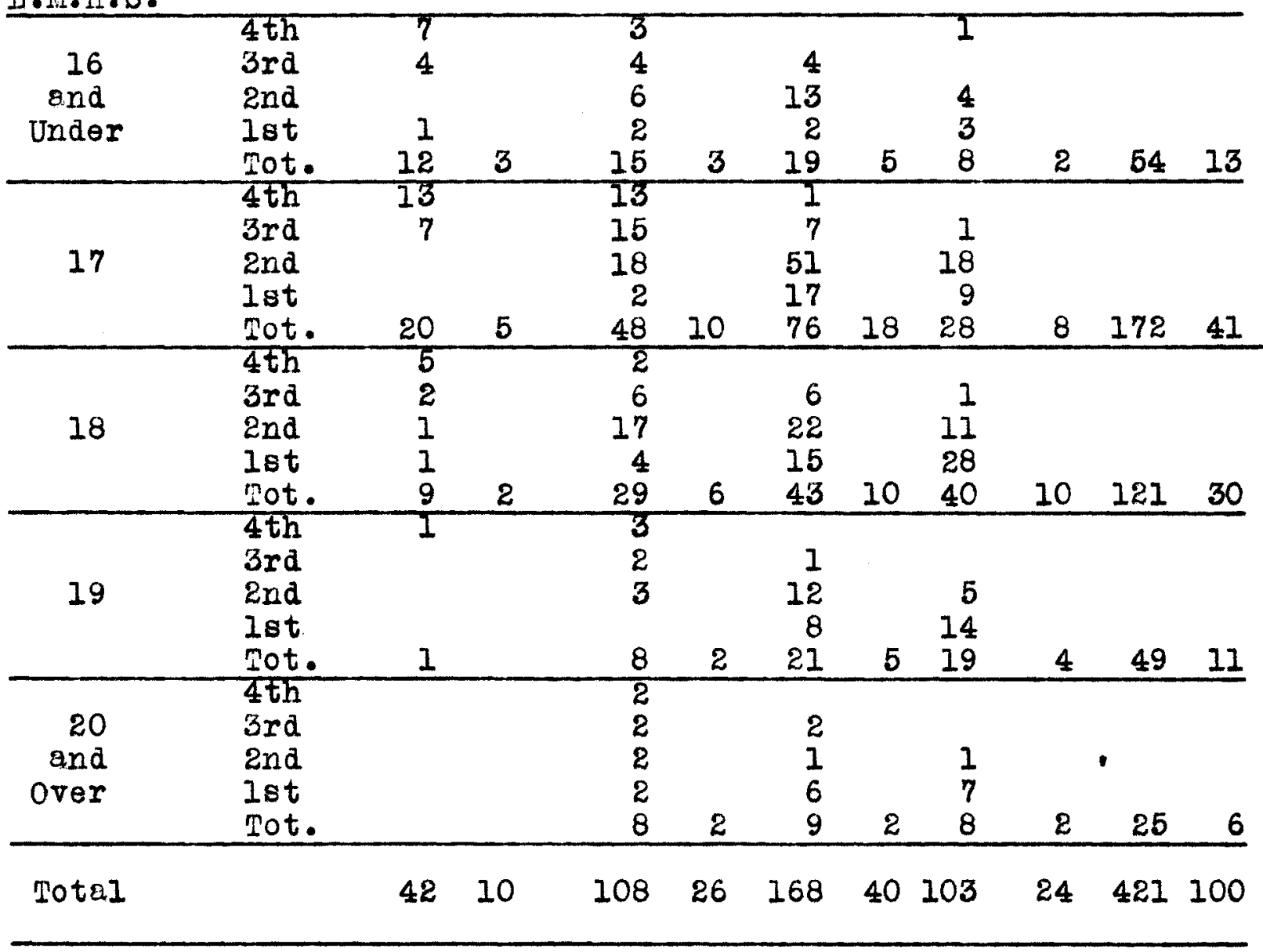


Twelve boys who were under 17 years of age gained 30 or more quality points, End 11 of these were in the two highest cuartiles. Twenty boys who were 17 yesrs old geined 30 quality points or more, and 20 were in the two highest quartiles. suggestion might be ventured that the boys of superior grades in I.M.H.S. under the gge of 18 gain 30 or nore quality points. The data for boys who gein from 15 to 30 quelity points refute this to some extent, because the gge does not seem to affect this group, nor does the quartile ranking. This fact seers to be substantiated by the group of $D$ grode, in which the cases gpoes to be distributed throughout the ge classificstions, a similer siturtion exists in the $m$ clessificetion.

The same number of boys 16 jerrs old or younger rated C or above es reted $D$ or below. Eleven ver cent more boys 17 yegrs old eerned $D$ or lower then $C$ or higher. No boy 20 Jears of ege or older averaged above $\mathrm{C}$ the Iirst seneter, and only one boy who was 19 yeere old eutergged ebove c. Sirtyseven per cent of the boys 18 jers old sversed below $\mathrm{C}$. The most positive statement mich cen be made is thet boys over 18 years of age th dete of praduetion probsby will averege belor: 3 .

mable 25 was arrenged for quertile renk by high school everege and olessified by gaplity point stending in the U. of 
I., with the consideration of the ages of graduates. A table of the two grade classificetions, quality points and quartiles, will be given to clarify the stetistics tabulated in rable 25 and to be compiled in other tables. The enelysis of mable 21 was to some extent based on the following table, which is a condensation of Table 21 with the percentages given. Theoretically, a boy in the highest quartile in the I.M.H.S. should be in the highest group at the $\mathrm{J}$. of $I_{.}, \mathrm{a}$ boy in the second highest quartile in I.H.H.S. should be in the second highest group at the U. of I., etc. Such $\theta$ condition would be true where there is perfect correspondence. Differences in systems of grading, (the U. oI I. grades on curve, I.M.H.S. does not), orientation or lack of it, personality clashes between instructor ona student, sre all factors in preventing complete correspondence.

TABLE 26

PARCENTAGES AND NUNB RS OH L.W.H.S. GRADUATES

SEPARATED ACCORDITG TO QUARTILES AID CIASSIFIED

BY NHS NUMBER OF QUAIITY POINGS ENCEIVED MHE FIRET SELTSTER AT THE U. OF I.

Quartile Number of quality roints 30 ned the First at Semester at the U. of $I$. I.If.i.s. 30 and over $15-301-15$ Less then 1 motal

\begin{tabular}{rrrrrrrrrrr} 
& INO. & \% & No. & \% & iNo. & \% & No. & $\%$ & No. & $\%$ \\
\hline 4th & 26 & 6 & 23 & 5 & 1 & & 1 & & 51 & 12 \\
3rd & 13 & 3 & 30 & 7 & 22 & 5 & 2 & & 67 & 16 \\
2nd & 1 & & 45 & 11 & 98 & 23 & 39 & 9 & 183 & 43 \\
Ist & 2 & & 10 & 2 & 47 & 11 & 61 & 14 & 120 & 29 \\
\hline Total & 42 & 10 & 108 & 25 & 168 & 41 & 103 & 24 & 421 & 100 \\
\hline
\end{tabular}


Fifty-one studente, 12\%, were in the fourth quartile at I.M.H.S., and 6 per cent of these were in the B or better group at the $U$. of $I$. Five per cent decressed their standing to the $\mathrm{C}$ group, one boy lowered his stending to the $\mathrm{D}$ group, and one boy dropped to the lowest group, which is equivalent to fallure at I.M.H.S.

Sixty-seven students, 16\%, were in the third quartile at I.H.H.S. and 7 per cent or less than half of these were in the C group a.t the U. of I. Five per cent dropped to the $D$ group, and 3 per cent roge one group number. Two boys fell as low as the first group.

one hundred eighty-three students, $43 \%$, were ranked in the second quartile at I.M.H.S., and 23 per cent of these were in the $D$ group at the U. of I. Eleven per cent rose by one group number, and 9 per cent lowered their stending one group number. One boy rose to the highest group.

One hundred twenty students, $29 \%$, were ranked in the lomest guartile at L.M.H.S. end 14 per cent of these remained in the failing group at the U. of $I$. Ileven per cent rose one group number and 2 per cent roce two numbers. Two boys who ranked in the lowest ougrtile at I..H.h.S. increased their stending to the highest group at the U. of $I$.

If we consider the data from the $U$. of I. point of view 
we notice thet $10 \%$ of the entire number were in the highest college group, and that practically all of this $10 \% 19 \%$ of the entire number) hed a high school averege of $85 \%$ or better. Twenty-five per cent geined between 15 and 30 quelity points, of which number practically as many averaged above $85 \%$ as averaged below it. Forty-one per cent were in the $D$ classification, of which number 34 per cent had an average below $85 \%$. Twenty-four per cent had a failing average at the U. of $L$. All of these hed filso a high school average below $85 \%$. Consideration of the reletionship between quality points earned the first semester and certein phases of the high school records will be continued. The number of credits earned in mathematics in I.M.H.S. was selected for comparison because the records were complete, four credits being required for graduation during the period covered by the study. Since four credite were required, we should expect to find an unusual number of students of all quartiles who did not pursue their studied in mathematics beyond the recuired courses. Three of the cases hod only two credits in mathematics, end because they were in different ones of the four classifications shown in the following table ord could not affect the totals, all three vere disregarded. 
TABLE 27

DERCENTAGES ATD NULBERS OF I.M.H.S. GRADUATES SEDARATED ACCORDING TO NURIBRR CF I.M.H.S. CREDITS IN MATHEIATICS AND CIASSIFIED BY THE NUURER OF QUAIITY POINMS RECEIVED THE FIRST SEIESTER AT MHE U. OF I.

No.

Credits Quar- Number of Quality Points Earned the in liath. tile First semester at the U. of $I$.

Earned at Less than at I.M.H.S. 30 and Over $15-301-15 \quad 1$ Total I.M.H.S. NO. \% No. $\%$ No. $\%$ No. $\%$ No. $\%$

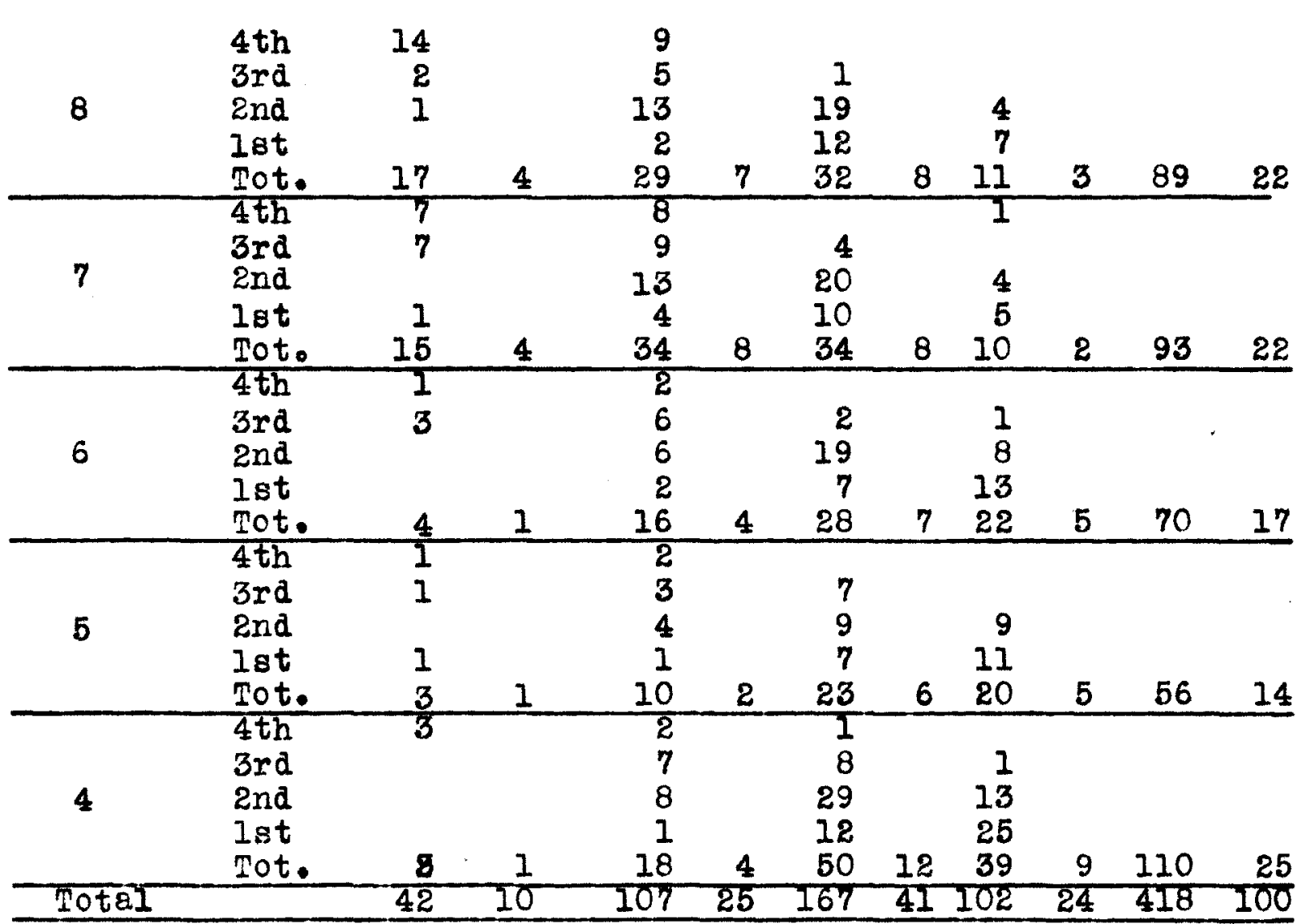


Forty-four per cent of L.M.H.S. graduates who entered

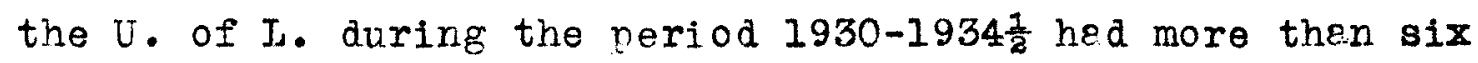
credits in mathematics. Seventy-five per cent of the graduates took more then the amount required for graduation.

The graduates who had eight credits in mathemetics were distributed over the four quality point groups, with the greatest number in the two midale groups. Thirty of thirtyone boys who averaged $85 \%$ or better had grades of c or better. The majority of those with an avergge of less than $85 \%$ in L.M.H.S. had on everage of less then $\mathrm{c}$ in the University. one boy who averggea lese than $85 \%$ had on averege of $B$ or better in the U. of $\mathrm{I}$.

The distribution of the greduates who had seven credits in matherstics is sinilar to thet of the greduetes who had eight credits in mathemetics. The boys with higher suergges in I.j.H.S. seem to gein higher averages in college regardless of the number of credits in methematics.

Seven boys who had five credits in methemetics had average of $85 \%$ or better end dropped to $D$ standing in college. Four boys who had even creaits in methemetics vith a similar cles ificetion in I....3. did the same in the U. Of I. No deductions cen be made irom that comperison.

It would appenr from the scettered distribution and 
the normel expectency from boys of the verious types thet the effect of methemetics upon the success of graduates is small. if there is any. The low gverege greduste apparently will remein a low averge college student whether he hes had seven credits or five credits in mathemetics. The high everage student usurliy obtgined a good avergge in college whether he had more than the reguired number of credite in mathematics or not. The high average graduate usually took more than the required number of credits in methemetics.

At this point, while we are discussing the distribution of greduates according to quality points in the U. of I. With the number of credits earned in methemetics, the veriove quartiles, etc. we might consider the tenure of the lowest one-third in each greduating cless. It will be necessary to recall the fact

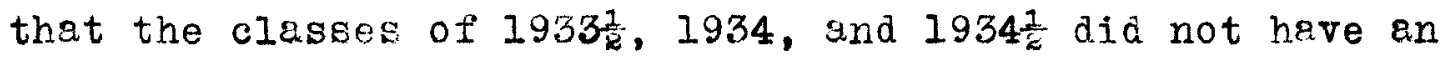
opportunity to attend the U. of $I$. more then seven, six, and five semesters respectively, since the date. were taken in the sumier of 1937. We shall average the totel number of semesters for erch class so thet a comperison may be made. since the cases are fev" in number a particuler class may have a high average, but for the ten clesses the averages should show a fairly eccurate picture of the tendencies for the lowest one third in rank of the gradugting clesses who entered the U. of I. 
TABIE 28

AVERAGLS OF NURDERS OF SBIPSTERS IN AMTENDATCE AT THE U. OM I. OF THE

LOWEST ONE-THIRD OF ELCH ON TEN CLASSES

GRADURTDD FROM I.H.H.S.

No.in Year of Groduation from I.M.H.S.

Gradua- $19301930 \frac{1}{2} 1931 \quad 1931 \frac{1}{2} 1932 \quad 1932 \frac{1}{2} 1933 \quad 1933 \frac{1}{2} 1934 \quad 1954 \frac{1}{2}$

ting

Class

$\begin{array}{llllllllll}123 & 114 & 140 & 105 & 203 & 136 & 197 & 122 & 240 & 133\end{array}$

No.

$\begin{array}{lllllllllll}\text { Enter- } & 33 & 42 & 34 & 35 & 70 & 38 & 46 & 31 & 71 & 36\end{array}$

ing

U. of I.

No. in

Lowest

one-

third

Entering

U. of I.

Av. NO.

$\begin{array}{lllllllllll}\text { of Ser. } & 4.1 & 3.5 & 3.5 & 6.0 & 2.4 & 3.3 & 2.5 & 3.2 & 1.8 & 2.3\end{array}$

for

Lowest

one-

third

AV.No.

$\begin{array}{lllllllllll}\text { of Sern. } & 4.7 & 4.3 & 4.9 & 3.6 & 4.3 & 3.7 & 3.4 & 3.4 & 3.4 & 3.1\end{array}$ for

Entire

class

The classes of $1930,1930 \frac{1}{2}, 1931 \frac{1}{2}, 1933,1933 \frac{1}{2}$ and $1934 \frac{1}{2}$ had averages for the lowest one third below the averages for the entire class in semesters ir attendance, but not significantly so. The class of $1931 \frac{1}{2}$ was exceptionel in the respect 
that the five boys who were in the lowest one third of their groúcting cless at I.H.H.S. Everaged 6.0 semesters in attendance at the $U$. of $I_{0}$, while the entire class everaged only 3.6 semesters in attendence. This was the only reversal of form, for the classes of 1931,1932 and 1934 avereged higher decisively than the lowest one third of the classes everaged. wich hes been written and more has been spoken ebout the effect of heredity upon intelligence. Perhans the choice of quality points is not the best criterion of intelligence, but we believe it to be sufficient for the following comparison, namely, occupation of parent with the number of quality points earned the first semester at the U. of I. The classification of the occupations for the most part wes not difficult because the categories vere sufficiently broad to include all cases. Whether to classify a horee trader as a professionel man or $8 \mathrm{~s}$ a merchant was puzzling for a time, until E compromise of salesman was made.

The seven categories finally decided on vere distinct from one enother; yet each contained a fairly well-balanced number of cases. Twenty-nine perents were housekeepers, and since housekeeping was not susceptible of being bracketed with any of the other occupations, the number was deemed sufficient to justify a separate closs. Before giving the comparison, we shall give a table of the categories. 


\section{TABLE 29}

IVUMBERS ON PAREITS AIDD PERCENTIGES OF THE

OCCUPAIONS OF PARENTS OF L.M.H.S. GRADUACES ATTENDING THE U. OF I., AND THE VARIOUS CLASSIFICATIONS OF EACH

Categories of the Occupations of Parents of L.M.H.S. Graduates

No. $\%$

particuler Occupations Grouped Under the categories
Executive

Professional

person

Merchant

Sale sman

clerk

Housekeeper

Skilled

Iaborer

Unskilled
53

13 Administrator, Director of Bank or Corporation, Maneger of a Lerge Business, Owner of an Industrial or commercial Business

6015 Physician, Dentist, Chiropractor, Minister, Jawyer, Teacher, Musician, Engineer (Civil, Chemical, etc.l, frchitect

7418 Hatter, Furrier, Junk Business, Weat shop, Druggist, Electric shop, Contractor, Trilor

6814 Auctioner, cake saleswoman, Bond salesman, saleslady, Real Estate selesman, Insurance, Horse Trader

5012 Agent (passenger, Income Tax, Government), Meil Clerk, Bookkeoper, Draftsman, Auditor, Librarian

29

7

5914 Plumber, carpenter, Foreman, MEson, Engineer (of Irsin). Mechanic, Motorman, Policeman, Butcher

25
6 Milkman, Mail Truck Driver, Farmer, Conductor 
The nurber of perents who are laborers is larger than the number in any other classification of occupations but not as lorge as one would expect. The occupetions of the perents of four hundred eighteen graduates were listed. Of the total number, 20\% are laborers, $18 \%$ are merchents, $15 \%$ are professional people, $13 \%$ ere executives, $14 \%$ are selesmen, and $12 \%$ are clerks. A totel of $46 \%$ belong to the class which might be termed leaders, since they are merchents, executives, or professional people. In ell of these crses the male parent is living and probably is the parent with whom the graduate resides, since under occupetion of perent on the form for taking the original data, his is the name listed.

An attempt was mede to correlete occupetion with quelity points gained by the method of the coefficient of Mean Square contingency, but insufficient data prevented the use of this method for either the individual classes or for the entire group. Perhaps instead of saying that the data were insufficient it would be more exact to say the data were not sufficiently well distributed. We used, therefore, the same method as ve used in Tables 25, 26, and 27, namely, percentages of aistribution. The date in meble 30 should be of some value in the argument of copital versus labor as regards the opportunity and the use of educrtional advantages as measured by quality points gained the first semester. We might combine 
the categories into executives, professional people, and merchants, as distinguished from salesmen, clerks, and leborers, or in other words higher saleried people ana lower salaried people. The classificetion of housekeepers is to be disregarded since it is i possible to clessify housekeepers according to income. The percenteges heve been computed to the nearest unit, a fact which accounts for discrepancies in totel percenteges. (see mable 30, page 91)

The first comperison will be the retio of the gredugtes Whose high school everage wes $85 \%$ and above to those whose averege was below $85 \%$, for each of the crtegories. The retio for Executives is 18 to 35, for selesven 18 to 51, for Clerks 15 to 35 , for Housekeepers 10 to 19 , for Skilled Isborers 8 to 51, and for Unskilled Laborers 3 to 22 . The ratio for higher saleried people is 64 to 123 , era for lower saleried people is 44 to 159 .

The next comperison will be the messurement of the success of the gradurtes by quelity points. The division is mede between those who hrve gr verige of $\mathrm{C}$ or better with those who heve en everage of less trien c. This division is not accurcte because some graductes took \& linter schedule, and the number of quelity points indiceting their success would be less then the number indicetirg success on the table. The retio for Rxecutives wes 53 to 20, ior Frofessional 
TEBLE 30

NUBERS LND PERCENTEES OF I.H.H.S. GRADUAMS SEPARATED ACUORDING TO OCCUEATIONS OH PARENMS LIND CLASSIRIED BY

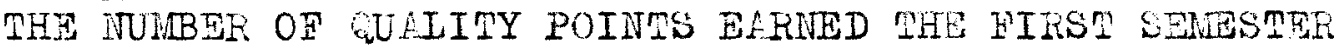
AT THE U. OF I.

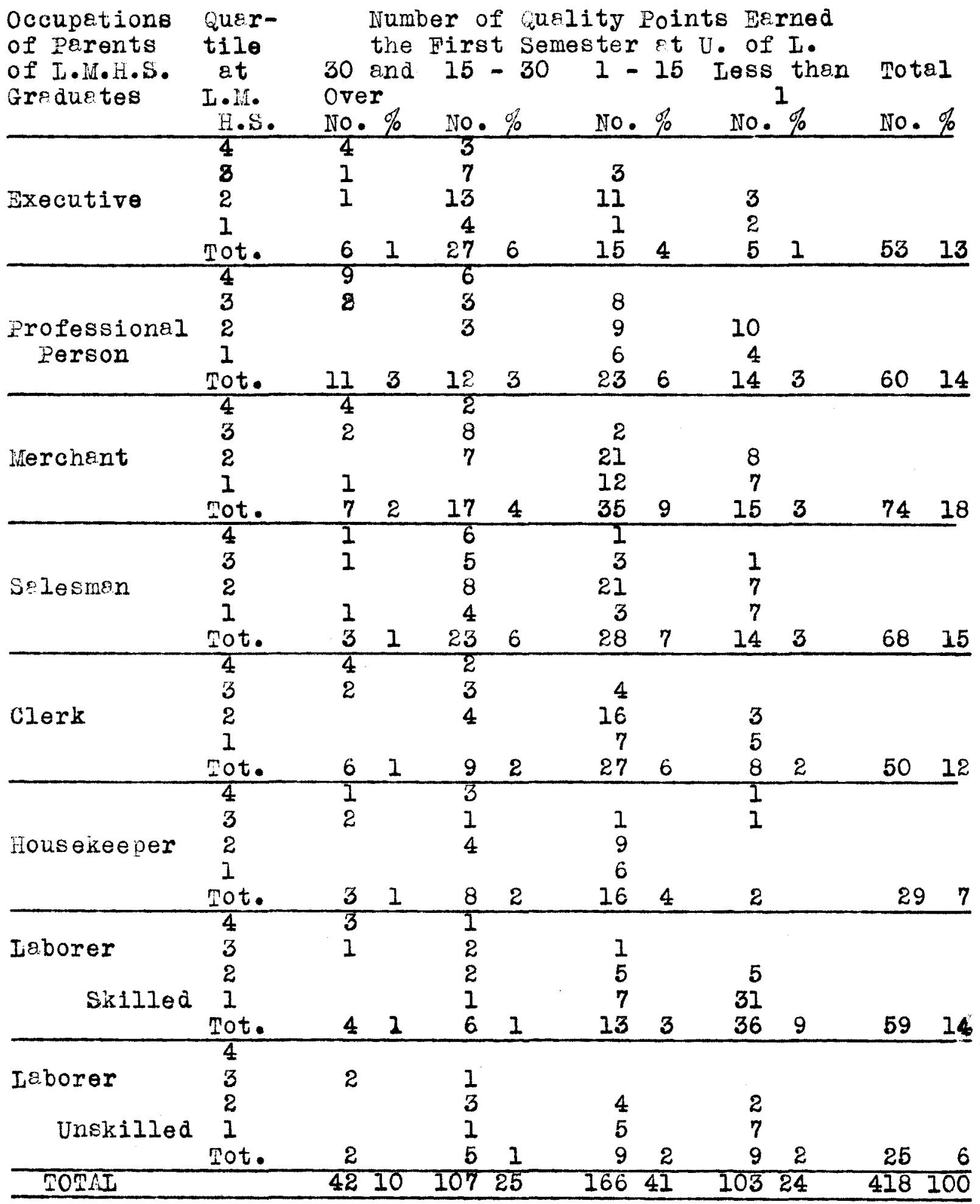


Persons 23 to 37 , for werchents 24 to 50 , for selesmen 26 to 42, for clerks 15 to 35, For Housekeepers 11 to 18 , for Skilled Iaborers 10 to 49 , end for Unskilled Iaborers 7 to 18. The ratio for higher salaried people is 80 to 107 , and for lover selaried people 58 to 144 .

Whe thira comperison will deel with the numbers of graduates who are out of position for esch of the classes of occupetions; that is, we shell find the greduetes whose high school average was $85 \%$ or above and who avereged lower than C in the $L_{\text {. of }} \mathrm{I} \cdot$, and conversely. Ihe ratio of those who averaged $85 \%$ or above and lower then $c$ to those who avereged below $85 \%$ and $\mathrm{c}$ or above for Executives is 3 to 18 , for Professionel Fersons 8 to 3 , for Herchants 2 to 8 , for salesmen 5 to 13, for Clerks 4 to 4 , for Housekeepers 3 to 4 , for Skilled Laborers 1 to 3 , and for Unskilled Leborers 0 to 4 . The comparison for higher salaried people is 13 to 29; and for lower selaried people, 10 to 24 .

The last comparison will consider the numbers of graduates who ere in position for each of the cetegories. In position means graductes whose high school aversge is $85 \%$ or above and whose college average is $\mathrm{C}$ or above and the opvosite. The ratio for Executives is 15 to 17, for Professional Persons 20 to 29, for lierchants 16 to 48 , for salesmen 13 to 38 , for 
Clerks 11 to 31, for Housekeepers 7 to 15, for Skilled Laborers 7 to 48 , and for Unskilled Ieborers 3 to 18. The corparison for higher salaried people is 51 to 94 , and for lower salaried people the ratio is 34 to 135.

The scholestic success, if $85 \%$ indicetes success, of the I.M.H.S. graduetes who attended U. of I. is greatest for sono of Professiongl Persons, then for sons of Housekeepers, Executives, Clerks, Salesmen, Herchants, Skilled Laborers, and Unskilled Laborers, in order. The collegiate success, if C indicates success, of I.H.H.S. graduates who attended the U. of I. is greatest for sone of Bxecutives, then for son of Professional Persons, Selesmen, Housekeepers, Nerchants, clerks, Unskilled Laborers, end skilled Iaborers in order. total of 82 graduates vere out of position, end 336 were in position. The predictive value of occupation of parent to success in college is fair.

A comparison of the intelligence of I.H.H.S. graduates who entered the $U$. of $I$. measured in each institution, was thought to be of value. Unfortunately, the number of graduates who had I.Q. Scores and scores on the Psychological Test were too scattered for individual classes. Five clesses had less than 20 cases, three classes had between 20 and 30 cases, and two classes had over 30 cases. The correletion between I.Q. scores and scores on the Psychologicel Test was .66I 
with a probable error of .023. Another reason for not using I. . scores was the fact thet some tests vere given in junior high school and some in senior high school, and thus measured greduetes et different ages. As the next best single item, it was thought that the everage of the high school graces could be correlated to the greatest advantege with the psychologicel mest as a criterion. The Psychological Fest was used because a greeter number of graduates hed scores on this test then on any other placement test, and also because it was thought thet such $\theta$ test measured intelligence more accurately than any of the other tests.

\section{TABLE 31}

CORFEL TION OF SCORTS ON NHE PSYCHOLOGICAI PLACHENT MYST IT THE U. OF I. VINH THE AVURLGS OF I.H.H.S. SCHOIASTIC GRLDES

Yeer of Greduetion from I.H.I.S.

Corre$1930 \quad 1930 \frac{1}{2} 1931 \quad 1931 \frac{1}{2} 1932 \quad 1932 \frac{1}{2} 1933 \quad 1933 \frac{1}{2} 1934 \quad 1934 \frac{1}{2}$

lation

$\begin{array}{lllllllllll}\text { of I.M. } & .254 & .570 & .555 & .517 & .619 & .593 & .487 & .529 & .521 & .546\end{array}$

H.S.AV. with scores on

Psych. test $(r)$

$\begin{array}{lllllllllll}\text { P.E. (r) } & .161 & .093 & .122 & .086 & .050 & .074 & .085 & .108 & .059 & .084\end{array}$ No. of

$\begin{array}{lllllllllll}\text { Cases } & 16 & 38 & 29 & 33 & 69 & 35 & 40 & 29 & 67 & 32\end{array}$ 
The datci indicate the fact thet there is a definite reletionship between the L.I.H.S. averages and scores mede by the graduates on the Psychological plecement rest. The coefficient of correletion should be at least four times the probable error to indicste some relstionship, which fact would invalidate the results for 1930 where $r$ ecuels .254 and the P.E. $(r)$ equals .16I. In $1930 \frac{1}{2}$ there is only a slight indication of relationship. Usurlly the $r$ should be five or six times the P.E. $(r)$ to show a decided correletion, and

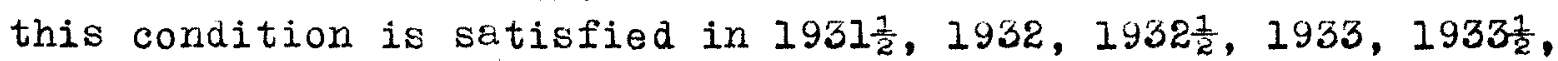
1934, and 1954 2 . The classes of 1932 and 1934, which were the largest, show 2 high correletion, in which the P.E. ( $r)$ is the lowest of the ten classes.

whether the requirement of four yeers of English in the I.I. I.S. is of value to the gradnate might be seen to some degree by the correspondence or non-correspondence of English grades in the high school with the gredes received the first yeer in college. Since we believe thet e certein amount of "grade getting" accrues to the individurl because of orientetion or femiliarity with school procedures, we took the four year average in English in I.I.H.S. rather than the junior-senior average only. The graues in the U. of I. are awarded by means of the letters $A, B, C, D, E$, and $F$, and those in I.M.H.S. by numbers from 70 to 100. We everaged the lotters lotting on $A$ ond $a$ B be represented by $B$ plus, $a$ B and 
$c$ by $c$ plus, etc. The peerson product-ioment formula for computing the coefficiert of correlstion was used.

PAEIT 32

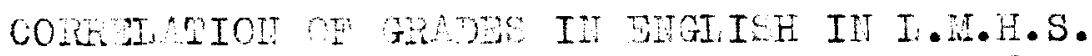

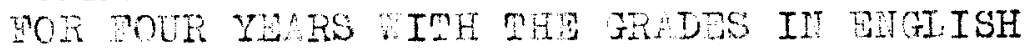

A THE U. OF I. TOK TH, EIRE YZIR

Year or Greaustion from I. ....S.

Corre-

$19301930 \frac{3}{2} 19311961 \frac{3}{2} 19321952 \frac{1}{2} 1933 \quad 1933 \frac{1}{2} 1934 \quad 1934 \frac{1}{2}$

lation

of

Eng.

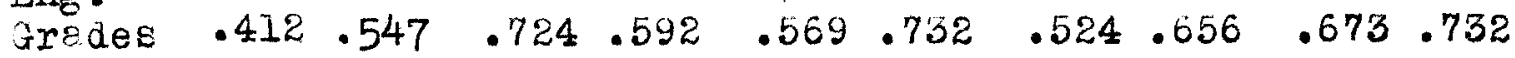

in I.I.

H.s.

with

Eng.

Grades

in

U. of I.

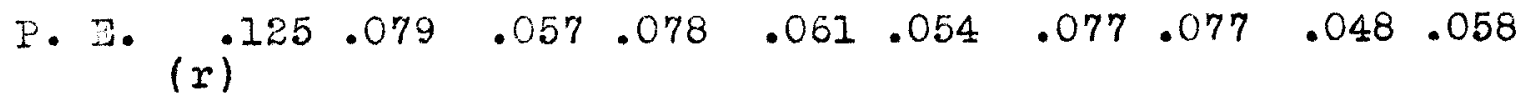

ITO. OI

ceses

$20 \quad 30$

$31 \quad 32$

$\begin{array}{llll}55 & 34 & 40 & 25\end{array}$

$58 \quad 29$

. Ve surmise from reble 32 thet 2 rel tionship between the gredes received in anglish et I.A...S. End groces received in anglish at the $U$. $O$. exists. Where the number of ceses is

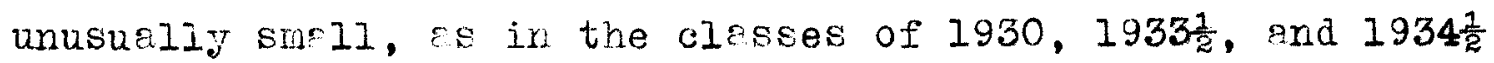
we may say thet reletionship is present, without saying that the correlstion is definite. But in the classes of 1930, 1931, 


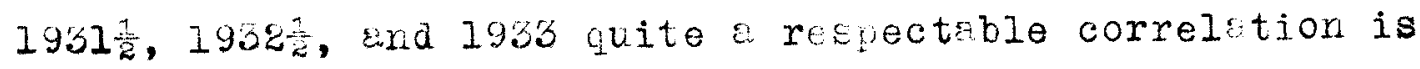
found. The number of crees is sufficient for the velidity of the forbile, and the P. E. $(r)$ is smell enough to allow the indicatior of corclusion; and in the two largest clesses, 1932 ard 1934, a definite reletion exists betweer English grades in the tro institutions.

The best iteria from the high school end college records for predictive purposes apor to be high school gredes and quelity point standings. Makie 33 shows quertile grounings for each criterion. For comlete crticrletion $\varepsilon$ stuaent in the fourth quertile in I.N.H.S. should be in the fourth quertile in the $U_{\text {. of }} I_{\text {. }}$, a studert ir the third quertile et I. W. . . should be in the third aurrile at the U. of I., etc.

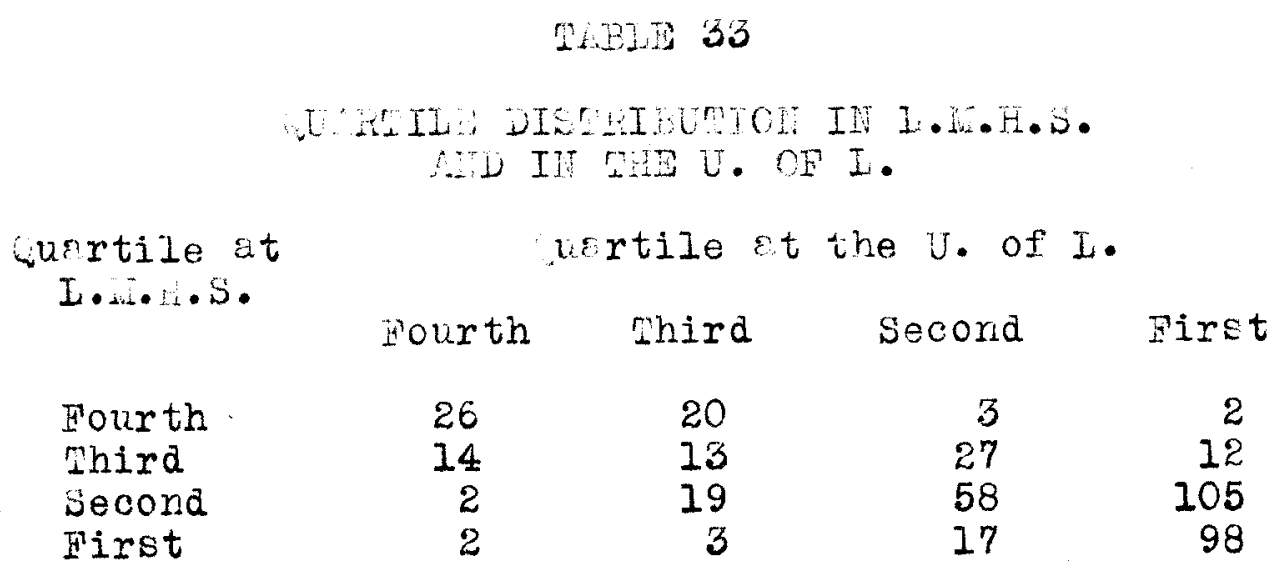

The dete of acte 33 inaicete the fact thet the mejority of students heve success comiensurate with their high school 
records. Hore students in the second quartile at I. in.H.S. renk in the first quartile at the $U$. of $I$. than either stay in the same quartile or advance to $\theta$ higher one. First quartile students appear to remain in the first quartile et the U. of I. Students in the fourth quertile may drop to the third quartile but selaom arop below the third quartile. Third quartile students mey be in any quartile at the U. of I. although more are in the second quartile than in sny other quartile.

The deta of mable 33 become more meeningful if we compute the chances of a I.H.I.S. student to renk in the verious quartiles at the U. of I.

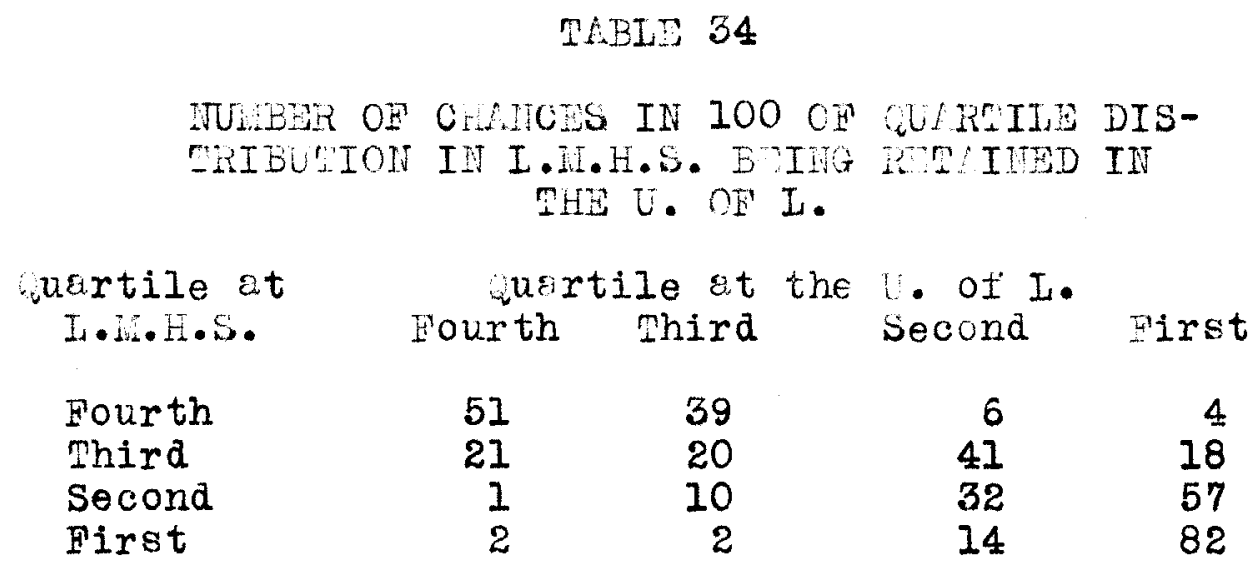

The chances ere 51 in 100 for a student in the fourth quartile at I.i.H.S. to be in the fourth quartile at the U. of I. The chences are 90 in 100 of a student in the fourth 
quertile at I.ivis.s. being above the second quartile at the U. OI I. A student in the third quartile has 21 chances in 100 of being in the fourth ausrtile or less than one half the chences of a fourth cusrtile student. A third quertile student has more chences of dropping to a lower quertile then he has of being in either the third or fourth quertiles. A student in the third quertile has four times as meny chances of being in the first uertile and seven times as meny chances of being in the second quartile as a student in the fourth quertile hes. L student in the second quertile hes one chance in 100 of being in the fourth quertile and 11 in 100 of being in either the third or fourth qusrtile et the U. OI I. A second quertile student hes 32 cherces in 100 of meiriteining his quertile stenaing and 57 in 100 of droping to the first quertile. A first quertile studert at I.M.H.S. has 82 chences in 100 of being in the first qurtile $\varepsilon t$ the $V$. of I. He has 4 chences in 100 of being in either of the two nighest quertiles, and 18 in 100 of improving his sterding.

s stuent in either of the two hishest quertiles at I.j.j.s. has 65 chances in 100 or boing in either of the two hirhest quertiles st the $J$. of $I$. in stucient in either of the two lowest guextiles t 1. ....5. hes 92 cherces ir 100 of being in either ol the two lowest quartiles st the U. of I. A student has 46 chances in 100 of beirg in the same guartile 
a.t the U. of I. as he is in at I.M.H.S.

Summary: Using the number of quelity points gained the first semester as a criterion, and the age when gradurted from L.M.H.S. es an item for comparison, the dete indicete thet age has little effect upon success in college. We may say that a boy over 19 will probebly rank below a $B$ average, and if he is in the first or second quartile he will likely average below $\mathrm{C}$. A student 16 years old or younger when graduated will probably receive $D$ or better, but in general no prediction of his success may be mede. The 18 year old graduate will most likely averege below $\mathrm{C}$, or it might be said more positively that if he is in the first or second quertile he will averege below B. Students 20 and older will probably average below $B$.

Data from the comparison of the same criterion with rank in class tend to show that students in upper quertiles get better grades at the U. of $I$. than the students in the lower quertiles.

When number of credits in methematics is used as the item in comparison with the criterion we surmise that boys who average $85 \%$ or better took more mathematics then boys who average less than $85 \%$. The answer to whether mathematica increased success in college cennot be given by the available data. The prodictive value of amount of mathemetics taken is very slight. 
Whe lovest one-thira of the grounting clesses epperently heve a shorter terure at the $U$. of $I$. then do the other graduates, but the difference is not unusually lerge. The lovest one-third may stey a much longer everege time than do the other two-thirds in particuler classes.

Nearly one-helf of I.H.H.S. greaustes who entered the U. of I. between 1930 and $1934 \frac{1}{2}$ vere sons of higher salaried people such as executives, professions people, and merchents. Whis, however, aid not seem to heve the enticiocted effect upon the cuslity points esrred the ciirst semester, which were feirly evenly divided among the categories regraciless of occupation. The predictive velue of occuption of perent for success in college is slight. The correletion of grodes in I.I.F.S. snd scores on the Psychologicel placement rest seems to indicate that these two criteria are good predictive items of success in college. A significent degree of reletionship is indicated by the correlations of four yesr english grades in I.W.i.s. vith freshnen English grades in the U. of I. This condition does not seem to be affected by the size of the classes stuaiea, although it mey be true only for these classes.

The greduates in the fourth and third ourtiles would be more likely to succeed then greduates in the second and first quertiles. This was to be expected. Students under 19 
a.t the tine of gradution from high school mey fall into any classification, ana those over 19 would probably average under $B$. Many boys whose high school average was below $85 \%$ attained $a c$ or better ronking in college, and a smaller number whose high school everage was $85 \%$ or above received college everage below $\mathrm{C}$. 
Chepter VII

BUILLY AND COMCIUSION 


\section{Chapter VII \\ SUMMARY AND COHCIUSION}

The investigation of the records of 422 I.M.H.S. graduates who entered the $U$. of $L$. was undertaken with the thought that a comparison by classes would be of value to both the high school and the college. The study should be of value to the teachers in I.H.H.S. in so much as a knowledge of the success of the gradurtes would extend the instructors' vision beyond the graduation of their students. The study should be of interest to the feculty of the U. of I. as it presents comparative information about the background of I.M.H.S. graduates. The average student at the U. of $I_{\text {. has been }}$ described as a gradiate of I.jin. is. The results of the tabuIations should aid counselors of the graduates entering the $U$. of I. both before and after admission to the college. Fleven questions were proposed in the introduction to the study, the answers to which were thought to be adequate for the scope of the investigetion. Meny apparently worthwhile phases suggested by the date could be examined, but because such procedure would cause the report to become unwieldy, the aforementioned cuestions were used to delimit the scope of the study.

1. The Louisville Courier-Journal, May 8, 1938 
Question 1. Do the graduates whose grades are highest enter the U. of L., go to other colleges, or enter no college?

The data for Table 2 are falrly complete, and if the averages of the grades are reliable we may believe that colleges other than the $U$. of $L$. get the higher ranking students. The differences do not seem to be appreciable, not nearly so great as the superiority of the graduate who enters the U. of L. over the graduate who does not enter any college.

Question 2. Do the graduates whose I.Q. scores are highest enter the U. of L., go to other colleges, or enter no college?

The data of Table 3 show, within the limits of the scores which were available, that the graduates who obtain the highest I.Q. scores go to colleges other than the U. of $I$. In one or two classes the group which does not enter college has the highest I.Q. scores. The U. of I. enrolls graduates who rank between the other two groups in $I \cdot Q$. scores. Perhaps it would be worth while to make an investigation of the high ranking graduates who do not enter college.

Question 3. Is the first year of college more difficult than the second? 
The dsta which heve been gethered sre not sufficient to enswer this question. Too neny factors enter into the question to gllow sriy positive or negetive reply.

question 4. Ifas the gge of the L.H.H.S. graduate any significance in his success in the college?

In general the anewer would be no. We see, however, from Mable 25 that the less mature graduetes, chronologicelly, appear to gain as mary quality points the first semester as the older graduetes. An explenetion of this mey be the fact that the younger students are often intellectually superior. The graduates are entering college with no appreciable varietion in their ages from year to year as shown by mable 5 . cuestion 5. When do the lowest one-third of the gradurting clesses drop out?

on an avergge the lowest one-third of the gradueting classes stay a shorter tine in the U. of $I$. then does the entire class. The dete of rable 28 sustain euch a stetement, the exception being a class in which there are few in the lowest one-third, all of whom apparently take college more seriously then they did high school.

question 6. Does the rank in the graduating class give an indication of the number of quality points earned the first semester? 
Whe data of rable 4 indicete that the graduetes who enter the $U$. of $I$. sre above the eversge graduate in renk in the graduating class. The number of credits is well above the number actually necessary to graduate, if the averages in rable 6 moy be taken as on index. Teble 26, in which the graduotes were separated by quertiles, chowed that the greatest number of quelity points was exrned by the greductes in the higher guartiles. We may say that those in the first and second quartiles will probably earn less than the average number of uglity points, a fact which mey be seen in pable 10. Pable 14 shows that in the ten classes studied, fourth quartile students for exceed the three other quartiles in number of chances of attaining high quality point standing. Ninety-six of 100 fourth cuartile studerts will rate a quelity point standing of 1.0 or better; 75 of 100 third quartile students will rate the same as compared with 31.5 of 100 in the second quartile end only 11 of 100 in the first quartile.

Question 7. Is there any relation between the occupation of the porent and the success of the gredunte the first semester?

The classification of the parents of graductes in Tablo 29 is such that the range of the percentages is rather small. The compilation of cable 30 would probebly be but little 
affected by the addition of a larger number of cases. The distribution seems to indicete the fact thet there is little if any advantage accruing to a greaugte because of the occupetion of his parent.

vuestion 8 . Does the study of netheratics increese a student's chences for success in college?

A lerge number of students take only the reauired amount of mathernetics in high school. Scettered emorig this number are high renking students, who heve better then everage success in college. reble 27 shows thet a graducte is not dependent upon the number of credits he has in methemetics for his success in college. The superior students take more then the recuired number of credits in mathemetics usurlly, but there is no indication thet the smount of mathematics makes a student stiperior in college.

quetion 9. Is there any correlation between the I........ Scholsetic everege and scores or the peychological Fest?

The dete computed in Fabie 31 imply thet the I.L.H.S. scholestic averse he definite relationship to the scores received on the psychologics I Fest. There is nore evidence of this relationship from the dete of reble 26 in which the percentages of the quertiles favor a greater number of quelity points for the gradurte of the jourth or third quertile. 
Question 10. Is there eny correlation between grades for English in I.M.I.S. and in the U. Of I.?

From mable 32 we see indicetions that there is a definite relation between grades received during four yeers in L.M.H.S. and gredes received the first year in the U. of I. Whether this cordition prevails for English for ell graductes of I.I.I.S. who attend the U. of $I$. is not definite, but the positiveness of the correlations seems to creste $\&$ presumption in that direction.

Question 11. Which group succeeds at the U. of I.? We divided the I.H.H.S. gre ulates into four group according to their high school avergge. cebles 15,16 , and 17 indicate that students in the highest quertile have a longer tenure than the students in the other custiles. Obversely the boys in the two lowest quertiles are in attendance a shorter time tran the boys in the two highest quertiles. The data for reble 23 show a positive correlstion between high school and college gredes for the first semester. A similar correlation is shown by mable 24, 1. greduate whose average is $85 \%$ or above, thet is, a graduste in one of the two upper quertiles, would receive higher grades than graduates whose averages are below $85 \%$. A boy in the first quartile would receive corresponãingly low gredes in the U. of I. This is confirmed by Table 13 end Teble 26. Table 27 indicates 
thet the amount of mathemetics is not proportionel to success. Iikewise age is not a determining factor in success, as shown by Table 5 and Table 25.

Conclusion: The everage graduate of the I.M.H.S., if

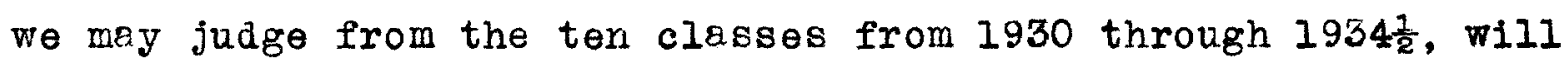
be \& member of a cless of 150 , with a high school average of 81.5, and an I.Q. score of 113. He will stand 68 th in his class when he is 18 years, one month of age, having earned 33.8 credits. When he takes the Placement rests at the U. of I., he will attain the 56 th percentile on the Psychological Test, the 50th percentile on the English rest, and the 5lst percentile on the Reading rest. During his first semester in the college he will earn 12 semester hours and 12 quality points, which will be increased the second semester to 12.8 semester hours and 13 quality points. The fourth semester will find the average graduate earning 13.5 hours and 16 pointe, with a totel of 56 hours and 67 points for the four semesters if he stays thet long. The average graduate is a different person in his second yeer, for meny who have made him rather inferior when he was a freshman will no longer be there. He will stey 3.5 semesters, but had he stayed four semesters with a $\mathrm{C}$ everage he could have taken the sophomore Comprehensive Tests.

On the sophomore Comprehensive rests he would have received a percentile ranking of 68 in social studies, 72 in 
Foreign Iiterature, 63 in Fine frts, 65 in Total General Culture, 55 in rotal English, 56 in Iiterary Acquaintance, 69 in Contemporary Affairs, 65 in General Science, and 60 in World History. He would then have the pleasure of knowing that he ranked well when compared with students in the nation's liberal arts colleges tested as he was.

In his freshman year, the average greduate would enroll In survey courses in English composition, Introduction to the study of society, and the History of Civilization. When he reached the sophomore year he would study a survey of the Humanties, and a Survey of the Netural sciences. For all courses he took when he was a freshmen he would average a Iow $C$, but when he was a sophomore he would improve to a good C average.

Therefore, the everage greduate of L.M.H.S. coula successfully attend the $U$. of $I$.

But what of the value of all this date for predictive purposes? Just what degree of correletion exists between high school and college records? The conclusions for the most part would seem obvious to the laymen. While the figures used to substentiate the corclusions may not be sufficiently inclusive, the correlation coefficients for those used are high.

But whet of the individuel student who detracts from a perfect correletion? The predictive velue of the tables 
is lowered by the possibility thet a low renking student may be successul in college, or $\varepsilon$ high ranking student may fail in college. The data show that a good student is more apt to go down than a poor student is to come up. The average student is successful, but often the average student is an imaginary person.

The degree of articulation between I.M.H.S. and the U. of I. is foir but could be improved. Differences in greding, in standards, and in the philosophy of the instructors, causes the articuletion to be lower then it should be. The writer recominends a personality chert for each graduate to supplement the records now used in admission procedure. The addition of such a chart might take care $O A$ individual differences of graduates. Many tables show the need for some method of providing for individuel differences, and the answer would seem to be the personality chart. 
BIBI IOGHPHY 


\section{BIFIIOGREDY}

Bremmel, P. Roy. "Articuletion of ligh School and college," Netiongl Survey of Secondery educetion, Nonogreph Ho. 10, U. S. Office of Bucetion, Bulletin No. 17, 1952.

Byrns, Ruth. "Yredicting college success by High School Grodes," The Nations Schools, JuIy, 1932.

Crewford, A. B. "Forecssting Ereshmen Achievement," School and Society, JErusry 15, 1930.

Edds, J. H. and Hocell, W. M. "Predicting the scholastic Success of College Freshmen," Journal of Educationel Research, october, 1933.

Eells, Walter C. "The Collegigte Success of Secondary School Graduates," Journal of the Americen sssociation of collegiate Registrers, April, I938.

Ferguson, George 0. Jr. "Some Factors in Predicting College success," School and society, April 29, 1933.

Ficken, c. E. "Predicting Achievement in the Iiberal srts College," School Ena Society, October 12, 1935.

Fifteenth Edition of the Louisville Mele Figh School 'H' Book, Press of the Theodore Ahrens Trsde school, Louisville, $\bar{K}$ entucky, 1937-1938.

Garrett, Henry E. Stetistics in Psychology end Educetion, Iongmans, Green and Co., NeW York, 1926.

Gledfelter, Jillerd $E$. Whe Value of Several criteria in Predicting College success," Journel of the friericen Associetion of Collegiete Registrers, Aoril, 1936.

Gledfelter, Jilierd E. "Stetus ana mrends of college Entrance Requirements," The School Review, December, 1937.

Gowen, J. W. and Gooch, M. "The Mentel litteinments of college Students in Reletion to Previous Training," Journal of

Eacational Psychology, November, 1925. 
Hertmen, Helen J. "Pre-College Guidence in Ohio," The School Review, November, 1937.

Johnston, J. B. and Williamson, E. G. "A Follow Up Study of Eerly Scholastic Predictions in the University of Minnesota," School and Society, December 1, 1934.

Mcelutty, John V. "Relgtive Scholarship of Graduetes According to Accreditation of High Schools," Journel of the American Associetion of Collegiate Registrars, hpriI, I934.

Newsom, N. William and Sturm, Morris H. "Comparison of the College and High School Marks of Hon-Gradueting College students," Journal of the American Associetion of Collegiate Registrars, April, 1937 .

Oppenheimer, J. J. Chapter 11 of what about Survey Courses? by Johnson, B. I., Henry Holt and Co., New York, 1937.

Pettengill, True E. "Comparison of the College Aptitude Test and Rank in High School Gradueting Class as Factors for Predicting Freshman Scholarship," Journal of the American Association of Collegiate hegistrars, hpril, 1936.

Pettengill, True E. "Size of High School and Predictive value of Class Rank end Aptitude Test Rank," Journal of the American Association of Collegiate Registrars, April, 1934.

Reitz, Wilhelm. "Predicting College Achievement with Marks and Ranks Adjusted for Inter-High School Variability," Journal of the Americen Association of collegiate Regietrars, Apri1, 1934.

Research Bulletin of the National Bducational Associstion, Werch, 1938 .

Segel, David. "Prediction of Success in College," Bulletin No. 15. U. S. Otfice of Education, U. S. Government Frinting Office, Washington, D. C., 1934.

Thurber, C. H. "Is Scholership kanking Useful for Prediction?" School and Society, iwarch II, 1933.

Tuttle, G. P. "The Predictive Velue of Renk in High School Gradueting Class," Journel of the American Association of Collegiate Registrers, Jonuery, 1937. 
Wood, Ben D. "The Ultimate Basis for satisfactory CollegeHigh School Relctions," Journal of the Americen Association of Collegiete Registrers, July, 1934

Zorbaugh, Grace S.M. and Kuder, G. Frederick. "College Grades and the Vocational sotive," School and Society, July 10, 1937 . 